\title{
Metabolic modeling of denitrification in Agrobacterium tumefaciens: a tool to study inhibiting and activating compounds for the denitrification pathway
}

\author{
Marlies J. Kampschreur ${ }^{1 *}{ }^{+}$, Robbert Kleerebezem ${ }^{1}$, Cristian Picioreanu ${ }^{1}$, Lars Bakken ${ }^{2}$ \\ Linda Bergaust ${ }^{3}$, Simon de Vries ${ }^{1}$, Mike S. M. Jetten ${ }^{1,4}$ and Mark C. M. van Loosdrecht ${ }^{1}$ \\ 1 Department of Biotechnology, Delft University of Technology, Delft, Netherlands \\ 2 Department of Plant and Environmental Sciences, Norwegian University of Life Sciences, Ás, Norway \\ ${ }^{3}$ Department of Chemistry, Biotechnology, and Food Sciences, Norwegian University of Life Sciences, Ás, Norway \\ ${ }^{4}$ Department of Microbiology, Radboud University Nijmegen, IWWR, Nijmegen, Netherlands
}

Edited by:

Boran Kartal, Radboud University,

Netherlands

\section{Reviewed by:}

James Moir, University of York, UK

Douwe Molenaar, VU University

Amsterdam, Netherlands

*Correspondence:

Marlies J. Kampschreur, Waterboard

Aa en Maas, Pettelaarpark 70,

5216 PP 's-Hertogenbosch,

Netherlands.

e-mail:mkampschreur@aaenmaas.nl

${ }^{\dagger}$ Present address:

Marlies J. Kampschreur, Waterboard

Aa en Maas, Pettelaarpark 70,

5216 PP 's-Hertogenbosch,

Netherlands.
A metabolic network model for facultative denitrification was developed based on experimental data obtained with Agrobacterium tumefaciens. The model includes kinetic regulation at the enzyme level and transcription regulation at the enzyme synthesis level. The objective of this work was to study the key factors regulating the metabolic response of the denitrification pathway to transition from oxic to anoxic respiration and to find parameter values for the biological processes that were modeled. The metabolic model was used to test hypotheses that were formulated based on the experimental results and offers a structured look on the processes that occur in the cell during transition in respiration. The main phenomena that were modeled are the inhibition of the cytochrome c oxidase by nitric oxide (NO) and the (indirect) inhibition of oxygen on the denitrification enzymes. The activation of transcription of nitrite reductase and NO reductase by their respective substrates were hypothesized. The general assumption that nitrite and NO reduction are controlled interdependently to prevent $\mathrm{NO}$ accumulation does not hold for A. tumefaciens. The metabolic network model was demonstrated to be a useful tool for unraveling the different factors involved in the complex response of $A$. tumefaciens to highly dynamic environmental conditions.

\section{Keywords: Agrobacterium tumefaciens, denitrification, metabolic model, nitric oxide, nitrite reduction, nitrous} oxide, NO reduction

\section{INTRODUCTION}

Denitrification is an important process in the global nitrogen cycle, which is investigated at many levels ranging from gene expression to global nitrogen fluxes. Denitrification is mostly performed by facultative denitrifiers, which reduce oxygen when available and switch to nitrate or nitrite after oxygen depletion. During denitrification nitrogen oxides are used as electron acceptor by an electron transport chain similar to that used in aerobic respiration (Zumft, 1997). A complete denitrification pathway comprises four subsequent steps: nitrate reduction, nitrite reduction, nitric oxide (NO) reduction and nitrous oxide $\left(\mathrm{N}_{2} \mathrm{O}\right)$ reduction. Each reduction step is catalyzed by a specific reductase enzyme.

Incomplete denitrification can give rise to emission of $\mathrm{NO}$ and $\mathrm{N}_{2} \mathrm{O}$ (e.g., Schuster and Conrad, 1992). Emission occurs when intermediates accumulate because the electron fluxes over the four subsequent denitrification steps are unbalanced or when incomplete pathways are present or expressed in denitrifying organisms (e.g., Ferguson, 1994). The emission of NO is unwanted as it is toxic while $\mathrm{N}_{2} \mathrm{O}$ is a potent greenhouse gas (Houghton et al., 2001) and dominant ozone-depleting substance (Ravishankara et al., 2009). A better understanding of the regulatory network of denitrifying bacteria may lead to development of strategies to prevent $\mathrm{NO}$ and $\mathrm{N}_{2} \mathrm{O}$ emission.

In metabolism, several levels of organization can be distinguished: the genome, transcriptome, proteome and metabolome. Cells regulate their metabolism in response to changes in their environment. While the genome is more or less constant, the transcriptome, proteome and metabolome respond to the actual environmental conditions. Current advances in molecular biology lead to a great increase in availability of genome sequences and transcriptomic, proteomic and metabolomic data. Consequently, there is a high demand for analysis of the generated data and use these data for a broader understanding of metabolic regulation, for which a metabolic model can be a good tool.

Induction of the denitrification pathway after oxygen depletion is regulated by multiple promoters for gene expression. Even though the promoters are comparable in many types of bacteria, the exact regulation mechanism depends on the type of microorganism (e.g., Rodionov et al., 2005). Gene expression responds to specific environmental conditions like oxygen and nitrogen oxides concentrations, and possibly other compounds like metal ions (Zumft, 1997). Many individual relationships between promoters and specific genes have been identified that play a role 
in the regulation of the denitrification process, but only limited information is available on the main factors governing the overall response during transition from aerobic to anoxic conditions. To characterize such overall response patterns, Bergaust et al. (2008) conducted batch experiments with $A$. tumefaciens. A. tumefaciens is a facultative denitrifying micro-organism. A. tumefaciens contains the genes for periplasmic dissimilatory nitrate reductase (nap), nitrite reductase (nirK), and NO reductase (norB), but it lacks the genes encoding $\mathrm{N}_{2} \mathrm{O}$ reductase (Wood et al., 2001). As a consequence, its final product of denitrification is $\mathrm{N}_{2} \mathrm{O}$.

Bergaust et al. monitored the response of A. tumefaciens to transition from aerobic to anoxic conditions in terms of substrate uptake and intermediate and end-product accumulation. Additionally, gene expression profiles of key enzymes were measured during the aerobic-anoxic transition. The results demonstrated unbalanced expression of denitrification enzymes under certain conditions, resulting in uncontrolled accumulation of NO. Despite the rigorous experimental approach, the authors were not able to find a coherent explanation for all the observations made, and the need for a formalized model-based analysis of the experiments was recognized (Bergaust et al., 2008). As the findings of Bergaust et al. (2008) indicated that gene expression played an important role in causing $\mathrm{NO}$ emission, it was concluded that the metabolic model should include genomic, proteomic and metabolic regulation. In this study, we have developed such a metabolic network model, which to our knowledge has not been attempted before for the denitrification pathway. The aims of the model were to test hypotheses on the most important factors in the regulation of the denitrification process during the transition from aerobic to anoxic conditions, to identify parameter values and to define a model framework that can be used to design further experiments.

\section{METHODS \\ MODEL DEVELOPMENT}

The model was developed based on oxic/anoxic transition experiments with A. tumefaciens as described extensively in Bergaust et al. (2008). The experiments were performed in $120 \mathrm{ml}$ serum flasks, containing growth medium supplemented with different concentrations of $\mathrm{KNO}_{2}$ or $\mathrm{KNO}_{3}$ and succinate as the only $\mathrm{C}$-source. The initial oxygen concentration in the headspace was varied. Full experimental data-sets that were used for mathematical modeling were obtained from experiments with 1 and 7\% oxygen in the headspace and $0.2,1$, and $2 \mathrm{mM}$ of nitrite or nitrate. The experiments with no nitrite and nitrate and without initial oxygen were excluded because of less well-defined starting conditions (always some oxygen intrusion) and interference of presence of minimal nitrogen in the trace element solution. Inocula of fully dispersed aerobically grown cells were injected into the flasks. The headspace $\mathrm{NO}, \mathrm{N}_{2} \mathrm{O}, \mathrm{O}_{2}$, and $\mathrm{CO}_{2}$ concentrations were monitored during oxygen depletion and subsequent anoxic respiration. Measured NO concentrations in the nitrate experiments were corrected for calibration errors in the data that were originally presented by Bergaust et al. (2008). The calibration error led to an under-estimation of NO concentrations above $400 \mathrm{nM}$.

The experiment with $1 \%$ oxygen in the headspace (corresponding to $\sim 10 \mu \mathrm{M}$ oxygen in the liquid) and $1 \mathrm{mM}$ nitrite as initial concentrations was used as reference experiment. The nitrite experiments were found more suitable for modeling because the concentrations of all nitrogen species involved were measured $\left(\mathrm{NO}, \mathrm{N}_{2} \mathrm{O}\right)$ or could be calculated using mass balances (nitrite). In the nitrate experiments, nitrite concentrations and nap expression were unknown, complicating the interpretation of the experimental data. For the reference experiment gene expression of NorB and NirK was analysed using RT-PCR. Gene expression data of the experiment conducted at $1 \mathrm{mM}$ nitrate and $1 \%$ initial oxygen concentration were used to identify NirK expression kinetics in relation to nitrite concentrations.

The model developed considers that A. tumefaciens converts succinate (electron donor and carbon source) with oxygen (aerobic respiration) or with nitrate, nitrite, and NO (denitrification steps). In the experiments denitrification rates are changing over time due to availability of electron acceptors $\left(\mathrm{O}_{2}\right.$, nitrate, nitrite, and NO) and varying enzyme concentrations. Consequently, denitrification is described in the metabolic model by two levels of cellular organization: (1) enzyme expression (in which DNA transcription and translation are lumped) and (2) enzyme activity leading to substrate conversion and microbial growth. The lumping of transcription and translation means that the model assumes that the rate of enzyme production is proportional to the mRNA level and that the response time for enzyme translation is insignificant. It is further assumed that the translation rate is equal for nap-, nirK-, and norB-transcripts. This simplification led to a good description of the reference experiment but could be responsible for the poor extrapolation of the model to other experiments. A scheme of the conversions and regulation factors of the denitrification pathway in A. tumefaciens as used in the metabolic model is shown in Figure 1 .

Several biological and chemical reactions occur in the liquid according to the stoichiometry, rate expressions and parameters described in the next section. Because the model was developed gradually from simple to more complex, new factors affecting the process were only included if this resulted in an unequivocal improvement of the description of the experimental data. The goodness of fit was analyzed by calculating the sum of squared error (SSE) between the experimental data and the modeled values for the gaseous concentrations of $\mathrm{O}_{2}, \mathrm{NO}, \mathrm{N}_{2} \mathrm{O}$, and $\mathrm{CO}_{2}$. The model complexity was minimized to avoid the introduction of a large number of non-identifiable parameters.

\section{MODEL COMPONENTS}

The model is based on batch (time-dependent) mass balances in the liquid and gas phase, for a number of chemical species, enzymes and microbial biomass. In the liquid phase the chemical species with concentrations changing in time are: oxygen $\left(C_{\mathrm{O}_{2}}\right)$, nitrate $\left(C_{\mathrm{NO}_{3}}\right)$, nitrite $\left(C_{\mathrm{NO}_{2}}\right)$, nitric oxide $\left(C_{\mathrm{NO}}\right)$, nitrous oxide $\left(C_{\mathrm{N}_{2} \mathrm{O}}\right)$, carbon dioxide $\left(C_{\mathrm{CO}_{2}}\right)$ and bicarbonate $\left(C_{\mathrm{HCO}_{3}}\right)$. All these concentrations are expressed in molar units. Timedependent enzyme (nitrate reductase $E_{\text {sat, nap }}$, nitrite reductase $E_{\text {sat, nir }}$, NO reductase $\left.E_{\text {sat, nor }}\right)$ and the Agrobacterium biomass concentrations $\left(C_{\mathrm{X}}\right.$ in $\left.\mathrm{C}-\mathrm{mol} / \mathrm{L}\right)$ are also considered. The model assumes a maximum enzyme concentration in the cell so that the relative dimensionless enzyme saturation, $E_{\mathrm{sat}}$, ranges from 


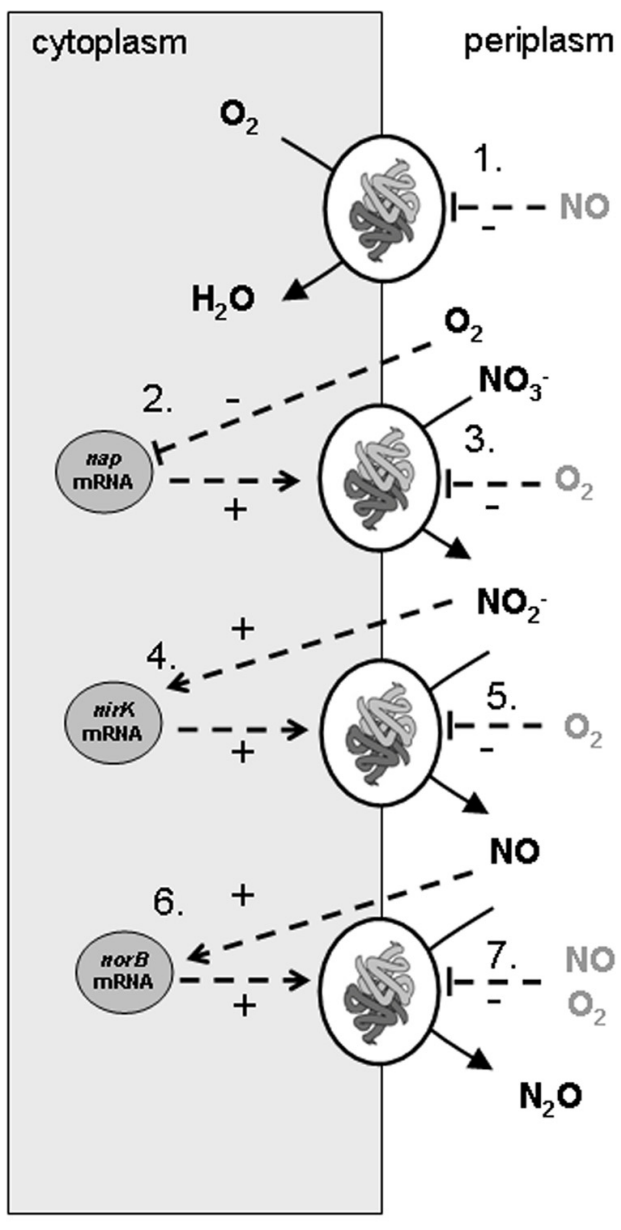

FIGURE 1 | Scheme of conversions and regulation of denitrification pathway in Agrobacterium tumefaciens as used in the metabolic model of the experiments. The combination of experimental data and the metabolic model led to identification of nirK and norB transcription activated by their substrates, nap transcription by oxygen limitation, apparent (indirect, via electron transport chain) oxygen inhibition of the denitrification conversions and NO inhibition on the cytochrome c oxidase. The processes that were modeled are: (1) oxygen reduction, (2) nitrate reductase synthesis, (3) nitrate reduction, (4) nitrite reductase synthesis, (5) nitrite reduction, (6) NO reductase synthesis, (7) NO reduction.

0 (absence of enzyme) to 1 . Succinate is present in excess and it is assumed not a rate limiting reactant, therefore it was not included in the kinetic model. It was also considered that the liquid is sufficiently buffered so that $\mathrm{pH}$ changes can be neglected and therefore $\mathrm{H}^{+}$concentration $C_{H}$ can be considered constant in time ( $\mathrm{pH}$ 7.5). In the gas phase there are four changing concentrations: oxygen $\left(c_{\mathrm{O}_{2}}\right)$, nitric oxide $\left(c_{\mathrm{NO}}\right)$, nitrous oxide $\left(c_{\mathrm{N}_{2} \mathrm{O}}\right)$, and carbon dioxide $\left(\mathrm{cO}_{2}\right)$.

\section{MODEL PROCESSES}

\section{Microbial conversions}

The model considers the microbial conversion of succinate as electron donor and carbon source with oxygen (respiration), or with nitrate, nitrite and NO (denitrification steps) as electron acceptors.
The stoichiometric equations were derived from redox balances and theoretical knowledge on growth yields, by using the procedures described in Stouthamer (1979) and Heijnen (1999). The following theoretical values were applied: $\mathrm{H}^{+} /$ATP ratio $=4$, ATP yield $=9.1 \mathrm{~g}$ dry weight biomass $/ \mathrm{mol}$ ATP, proton translocation on oxygen $10 \mathrm{H}^{+} / \mathrm{NADH}, 8 \mathrm{H}^{+} / \mathrm{FADH}_{2}$, and during denitrification $6 \mathrm{H}^{+} / \mathrm{NADH}$ and $4 \mathrm{H}^{+} / \mathrm{FADH}_{2}$ (Wasser et al., 2002). It was assumed in the derivation of reaction stoichiometry that ammonium (present as trace element) was used for $\mathrm{N}$ incorporation into biomass. The biomass molar weight is $24.6 \mathrm{~g}$ dry weight/C-mol $\left(\mathrm{CH}_{1.8} \mathrm{O}_{0.5} \mathrm{~N}_{0.2}\right)$.

The reaction rates are based on conventional substrate affinity expressions (Monod or Michaelis-Menten) with linear dependency on the biomass concentration $C_{X}$ and the specific enzyme levels $E_{\text {sat }}$. The electron acceptor consumption rates were assumed to be limited by the maximum succinate oxidation rate and therewith independent of the electron acceptor (Beun et al., 2000) as shown for Paracoccus denitrificans (Thomsen et al., 1994). The maximum specific succinate uptake rate was calibrated by fitting to the measured oxygen uptake profile.

For oxygen respiration, a competitive inhibition term for $\mathrm{NO}$ on oxygen respiration was applied. In the NO reduction process, substrate inhibition occurs at micromolar concentrations (Girsch and de Vries, 1997), and was modeled by standard Haldane kinetics. Because two NO molecules are consumed for generation of $\mathrm{N}_{2} \mathrm{O}$, the reaction is second order with respect to $\mathrm{NO}$ (Girsch and de Vries, 1997). Oxygen inhibits nitrite and NO reduction on the conversion level, not enzyme synthesis level as it can be concluded based on RT-PCR for NirK and NorB. Due to the strong oxygen inhibition, a power function on the conventional inhibition terms was needed.

With these assumptions, the molar stoichiometry and the rates (mol succinate $\mathrm{L}^{-1} \mathrm{~h}^{-1}$ ) of the four considered microbial pathways are:

(1) Aerobic conversion of succinate:

$$
\begin{aligned}
& \mathrm{C}_{4} \mathrm{H}_{4} \mathrm{O}_{4}^{2-}+1.2 \mathrm{O}_{2}+1.56 \mathrm{H}^{+}+0.44 \mathrm{NH}_{4}^{+} \\
& \rightarrow 2.2 \mathrm{CH}_{1.8} \mathrm{O}_{0.5} \mathrm{~N}_{0.2}+1.8 \mathrm{CO}_{2}+1.68 \mathrm{H}_{2} \mathrm{O}
\end{aligned}
$$

with rate:

$$
r_{\text {suc }, \mathrm{O}_{2}}=q_{m} \times C_{X} \times \frac{\mathrm{C}_{\mathrm{O}_{2}}}{\mathrm{~K}_{\mathrm{O}_{2}}\left(1+\frac{\mathrm{C}_{\mathrm{NO}}}{\mathrm{K}_{\mathrm{I}, \mathrm{NO}, \mathrm{O}_{2}}}\right)+\mathrm{C}_{\mathrm{O}_{2}}}
$$

(2) Nitrate reduction with succinate:

$$
\begin{aligned}
& \mathrm{C}_{4} \mathrm{H}_{4} \mathrm{O}_{4}^{2-}+3.23 \mathrm{NO}_{3}^{-}+1.64 \mathrm{H}^{+}+0.36 \mathrm{NH}_{4}^{+} \\
& \quad \rightarrow 1.8 \mathrm{CH}_{1.8} \mathrm{O}_{0.5} \mathrm{~N}_{0.2}+3.23 \mathrm{NO}_{2}^{-}+2.2 \mathrm{CO}_{2}+1.92 \mathrm{H}_{2} \mathrm{O}
\end{aligned}
$$

with rate:

$$
\begin{aligned}
r_{\text {suc }, \mathrm{NAP}}= & q_{m} \times C_{X} \times E_{\text {sat }, \mathrm{NAP}} \\
& \times \frac{\mathrm{C}_{\mathrm{NO}_{3}}}{\mathrm{~K}_{\mathrm{NO}_{3}}+\mathrm{C}_{\mathrm{NO}_{3}}} \times \frac{\mathrm{K}_{\mathrm{I}, \mathrm{O}_{2}, \mathrm{NAP}}^{\mathrm{nNAP}}}{\mathrm{K}_{\mathrm{I}, \mathrm{O}_{2}, \mathrm{NAP}}^{\mathrm{nNP}}+\mathrm{C}_{\mathrm{O}_{2}}^{\mathrm{nNAP}}}
\end{aligned}
$$


(3) Nitrite reduction with succinate:

$$
\begin{aligned}
& \mathrm{C}_{4} \mathrm{H}_{4} \mathrm{O}_{4}^{2-}+6.45 \mathrm{NO}_{2}^{-}+8.09 \mathrm{H}^{+}+0.36 \mathrm{NH}_{4}^{+} \\
& \quad \rightarrow 1.8 \mathrm{CH}_{1.8} \mathrm{O}_{0.5} \mathrm{~N}_{0.2}+6.45 \mathrm{NO}+2.2 \mathrm{CO}_{2}+5.15 \mathrm{H}_{2} \mathrm{O}
\end{aligned}
$$

with rate:

$r_{\text {suc }, \mathrm{NIR}}=q_{m} \times C_{X} \times E_{\text {sat, } \mathrm{NIR}} \times \frac{\mathrm{C}_{\mathrm{NO}_{2}}}{\mathrm{~K}_{\mathrm{NO}_{2}}+\mathrm{C}_{\mathrm{NO}_{2}}} \times \frac{\mathrm{K}_{\mathrm{I}, \mathrm{O}_{2}, \mathrm{NIR}}^{\mathrm{nNIR}}}{\mathrm{K}_{\mathrm{I}, \mathrm{O}_{2}, \mathrm{NIR}}^{\mathrm{nNIR}}+\mathrm{C}_{\mathrm{O}_{2}}^{\mathrm{nNIR}}}$

(4) NO reduction with succinate:

$$
\begin{aligned}
& \mathrm{C}_{4} \mathrm{H}_{4} \mathrm{O}_{4}^{2-}+6.45 \mathrm{NO}+1.64 \mathrm{H}^{+}+0.36 \mathrm{NH}_{4}^{+} \\
& \quad \rightarrow 1.8 \mathrm{CH}_{1.8} \mathrm{O}_{0.5} \mathrm{~N}_{0.2}+3.23 \mathrm{~N}_{2} \mathrm{O}+2.2 \mathrm{CO}_{2}+1.92 \mathrm{H}_{2} \mathrm{O}
\end{aligned}
$$

with rate:

$$
\begin{aligned}
r_{\text {suc }, \mathrm{NOR}}= & q_{m} \times C_{X} \times E_{\mathrm{sat}, \mathrm{NOR}} \\
& \times \frac{\mathrm{C}_{\mathrm{NO}}^{2}}{\left[\mathrm{C}_{\mathrm{NO}} \times\left(1+\frac{\mathrm{C}_{\mathrm{NO}}}{\mathrm{K}_{\mathrm{I}, \mathrm{NO}}}\right)+\mathrm{K}_{\mathrm{NO}}\right]^{2}} \\
& \times \frac{\mathrm{K}_{\mathrm{I}, \mathrm{O}_{2}, \mathrm{NOR}}}{\mathrm{K}_{\mathrm{I}, \mathrm{O}_{2}, \mathrm{NOR}}+\mathrm{C}_{\mathrm{O}_{2}}}
\end{aligned}
$$

\section{Enzyme synthesis}

For the enzyme synthesis Michaelis-Menten kinetics was assumed as a function of the enzyme inducer concentrations. A further saturation factor $\left(1-E_{\mathrm{sat}}\right)$ was introduced to limit the enzyme concentration in the cells (Wild et al., 1994). The model assumes a dimensionless enzyme saturation, in which the enzyme concentration ranges from absence of enzyme $\left(E_{\mathrm{sat}}=0\right)$ to maximum enzyme concentration in the cell $\left(E_{\mathrm{s} a t}=1\right)$. The experimentally observed rates of expression were different for the individual denitrification enzymes, i.e., nor expression is quicker than nir expression. The NAP, NirK, and NorB transcription were activated by their respective substrates nitrate, nitrite, and NO. Additionally the nap transcription was inhibited by oxygen. Because oxygen respiration is constitutively expressed, enzyme synthesis is not considered for this process. The model does not take enzyme decay into account because this was not necessary to describe the experimental data. Additionally, experimental data with repetitive oxygen addition to batch flasks indicated that enzyme decay for oxygen respiration is negligible for the time-scale of these experiments.

With these assumptions, the enzyme synthesis rates $\left(\mathrm{h}^{-1}\right)$ are:

(1) Synthesis of nitrate reductase nap:

$$
\begin{aligned}
\frac{d E_{\mathrm{sat}, \mathrm{NAP}}}{d t} & =v_{\mathrm{m}, \mathrm{NAP}} \times \frac{\mathrm{C}_{\mathrm{NO}_{3}}}{\mathrm{~K}_{\mathrm{NO}_{3}, \mathrm{NAP}}+\mathrm{C}_{\mathrm{NO}_{3}}} \\
& \times \frac{\mathrm{K}_{\mathrm{I}, \mathrm{O}_{2}, \mathrm{NAP}}}{\mathrm{K}_{\mathrm{I}, \mathrm{O}_{2}, \mathrm{NAP}}+\mathrm{C}_{\mathrm{O}_{2}}} \times\left(1-E_{\mathrm{sat}, \mathrm{NAP}}\right)
\end{aligned}
$$

(2) Synthesis of nitrite reductase nir:

$$
\frac{d E_{\mathrm{sat}, \mathrm{NIR}}}{d t}=v_{\mathrm{m}, \mathrm{NIR}} \times \frac{\mathrm{C}_{\mathrm{NO}_{2}}}{\mathrm{~K}_{\mathrm{NO}_{2}, \mathrm{NIR}}+\mathrm{C}_{\mathrm{NO}_{2}}} \times\left(1-E_{\mathrm{sat}, \mathrm{NIR}}\right)
$$

(3) Synthesis of NO reductase nor:

$$
\frac{d E_{\mathrm{sat}, \mathrm{NOR}}}{d t}=v_{\mathrm{m}, \mathrm{NOR}} \times \frac{\mathrm{C}_{\mathrm{NO}}}{\mathrm{K}_{\mathrm{NO}, \mathrm{NOR}}+\mathrm{C}_{\mathrm{NO}}} \times\left(1-E_{\mathrm{sat}, \mathrm{NOR}}\right)
$$

\section{NirK transcription}

Based on the experimental data of Bergaust et al. (2008) it was hypothesized that the transcription of nirK is activated by its substrate nitrite. This could be identified based on the experiments at $1 \%$ initial oxygen in the gas phase combined with $1 \mathrm{mM}$ nitrite or nitrate (Figure 2). The substrate concentration dependency of nirK transcription was modeled using saturation kinetics. In the nitrite experiment, nirK is rapidly transcribed from the start. The maximum specific nirK transcription rate was identified by the increase in nirK mRNA at non-limiting nitrite concentration (first $20 \mathrm{~h}$ in Figure 2). In the nitrate experiment nirK is only transcribed when the nitrite concentration has increased after nitrate reduction is initiated. The affinity constant for nitrite of nirK transcription (see Table 1) was deduced from the data obtained from the nitrate experiment (Figure 2, panel B). Here it can be seen that nirK transcription increases upon the increase in nitrite concentration.

Our observation that nitrite activates nirK transcription in A. tumefaciens does not correlate with the observations of Baek and Shapleigh (2005). These authors suggested that NO induces nir expression as well as nor expression (see next paragraph). However, it is known that the two genes are differentially regulated (Baek et al., 2008) and our experimental data clearly show nir expression before NO appearance. Also a two-step mechanism can be proposed with low level nirK transcription when nitrite is present and increased transcription when NO increases due to nitrite reduction (as postulated for Rhodobacter sphaeroides, Baker et al., 1998). The nirK transcription measurements do show a low transcription level during the first hours when oxygen is still present (Figure 2) which can support this hypothesis. It cannot be excluded based on the experimental data that decrease in oxygen concentration also plays a role in the transcription regulation.

\section{NorB transcription}

The induction of NO reductase expression by NO in A. tumefaciens, was previously shown (Baek and Shapleigh, 2005). The activation of norB transcription by $\mathrm{NO}$ can be deduced from panel A2 in Figure 2, where norB transcripts appear as soon as NO is measured. However, NO concentrations are very low, meaning that the affinity for $\mathrm{NO}$ is very high. These observations suggest that nitrite activates nirK transcription and NO stimulates norB transcription, which leads to a satisfactory model fit for the reference experiment (Figure 3). However, as indicated before, the enzyme synthesis parameters could not accurately be identified due to limited experimental data during the transition period. The maximum rate of transcription of norB is higher than the transcription rate for nirK. This can clearly be seen from the rapid increase in nor $B$ concentration after $\mathrm{NO}$ is detected, while nirK increases slower despite continuous nitrite presence. 

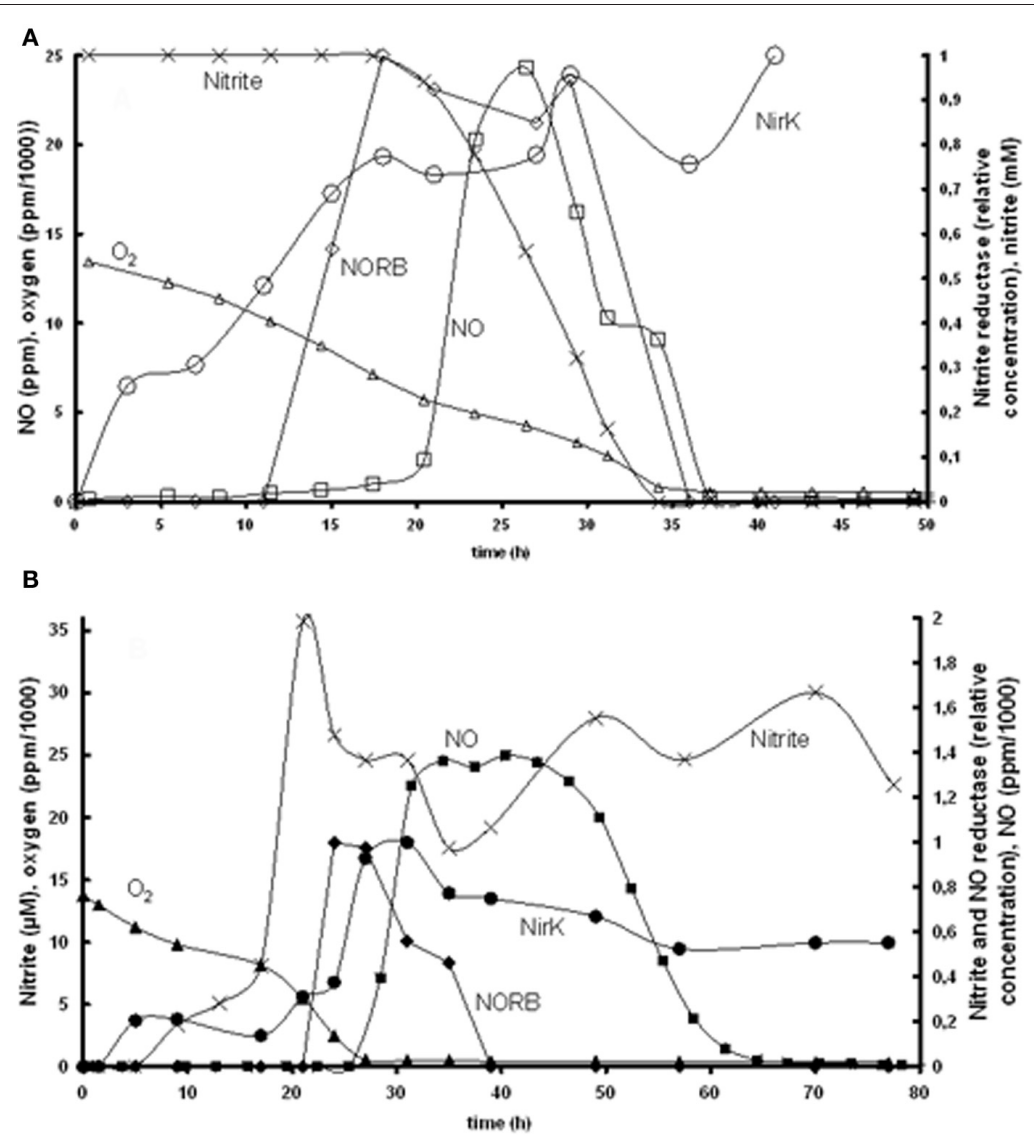

FIGURE 2 | Measured nirK and norB transcription together with concentrations of nitrate, nitrite, $\mathrm{N}_{2} \mathrm{O}$, and $\mathrm{O}_{2}$ in time. (A)

Experiment with $1 \%$ gas phase oxygen and $1 \mathrm{mM}$ nitrite: nitrite $(x)$, NirK $(\bigcirc)$, NORB $(\diamond)$ NO $(\square)$, oxygen $(\triangle)$. (B) Experiment with $1 \%$ gas phase oxygen and $1 \mathrm{mM}$ nitrate; nitrite $(x)$, NirK $(\bullet), \operatorname{NORB}(\downarrow), \mathrm{NO}$

$(\boldsymbol{\Lambda})$. Due to required amount of biomass for PCR analysis these experiments comprised several parallel flasks, see Bergaust et al. (2008) for details about the experiments.

\section{Chemical conversions}

The aqueous equilibrium between $\mathrm{CO}_{2}$ and $\mathrm{HCO}_{3}^{-}$was introduced in order to calculate the concentration of produced $\mathrm{CO}_{2}$ in the gas phase as a function of $\mathrm{pH}$ :

$$
\mathrm{CO}_{2}+\mathrm{H}_{2} \mathrm{O} \rightleftharpoons \mathrm{HCO}_{3}^{-}+\mathrm{H}^{+}
$$

with rate:

$$
r_{\mathrm{car}}=k_{\mathrm{car}} \times\left(\mathrm{C}_{\mathrm{CO}_{2}}-\frac{\mathrm{C}_{\mathrm{HCO}_{3}} \mathrm{C}_{H}}{K_{\mathrm{a}, \mathrm{car}}}\right)
$$

Because compared with the time scale of the whole process this equilibrium is very fast, an arbitrarily very large value was set for $k_{\text {car }}$.

\section{MASS BALANCES FOR CHEMICAL AND MICROBIAL COMPONENTS}

In the liquid volume (batch operation) the following mass balances are solved to find the concentrations of chemical species and biomass:

$$
\begin{aligned}
\frac{d \mathrm{C}_{\mathrm{O}_{2}}}{d t} & =-1.2 r_{\text {suc, } \mathrm{O}_{2}}+r_{\mathrm{tr}, \mathrm{O}_{2}} \\
\frac{d \mathrm{C}_{\mathrm{NO}_{3}}}{d t} & =-3.23 r_{\text {suc, NAP }}
\end{aligned}
$$

$$
\begin{aligned}
& \frac{d \mathrm{C}_{\mathrm{NO}_{2}}}{d t}=3.23 r_{\text {suc, NAP }}-6.45 r_{\text {suc }, \mathrm{NIR}} \\
& \frac{d \mathrm{C}_{\mathrm{NO}}}{d t}=6.45 r_{\mathrm{suc}, \mathrm{NIR}}-6.45 r_{\mathrm{suc}, \mathrm{NOR}}+r_{\mathrm{tr}, \mathrm{NO}} \\
& \frac{d \mathrm{C}_{\mathrm{N}_{2} \mathrm{O}}}{d t}=3.23 r_{\mathrm{suc}, \mathrm{NOR}}+r_{\mathrm{tr}, \mathrm{N}_{2} \mathrm{O}} \\
& \frac{d \mathrm{C}_{\mathrm{CO}_{2}}}{d t}=1.8 r_{\text {suc }, \mathrm{O}_{2}}+2.2\left(r_{\text {suc }, \mathrm{NAP}}+r_{\text {suc }, \mathrm{NIR}}+r_{\text {suc }, \mathrm{NOR}}\right) \\
& -r_{\mathrm{car}}+r_{\mathrm{tr}, \mathrm{CO}_{2}} \\
& \frac{d \mathrm{C}_{\mathrm{HCO}_{3}}}{d t}=r_{\mathrm{car}} \\
& \frac{d \mathrm{C}_{X}}{d t}=2.2 r_{\text {suc }, \mathrm{O}_{2}}+1.8\left(r_{\text {suc }, \mathrm{NAP}}+r_{\text {suc }, \mathrm{NIR}}+r_{\text {suc }, \mathrm{NOR}}\right)
\end{aligned}
$$

For the gas volume (batch operation) there is only mass exchange with the liquid phase, for each gaseous species $\left(i=\mathrm{O}_{2}, \mathrm{CO}_{2}, \mathrm{NO}\right.$, $\left.\mathrm{N}_{2} \mathrm{O}\right)$ :

$$
\frac{d c_{i}}{d t}=-r_{\mathrm{tr}, i} \frac{V_{L}}{V_{G}}
$$


Table 1 | Model parameters.

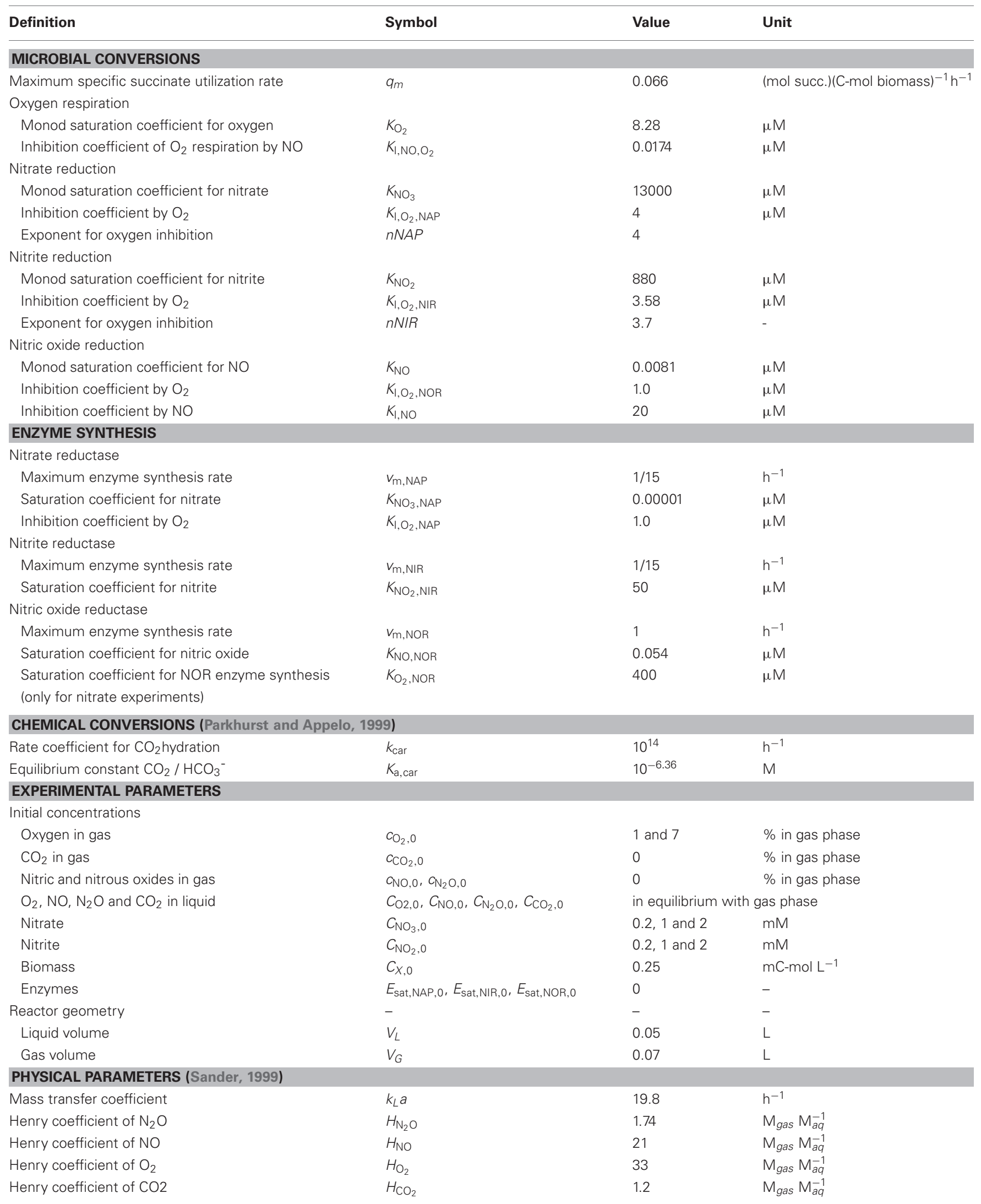




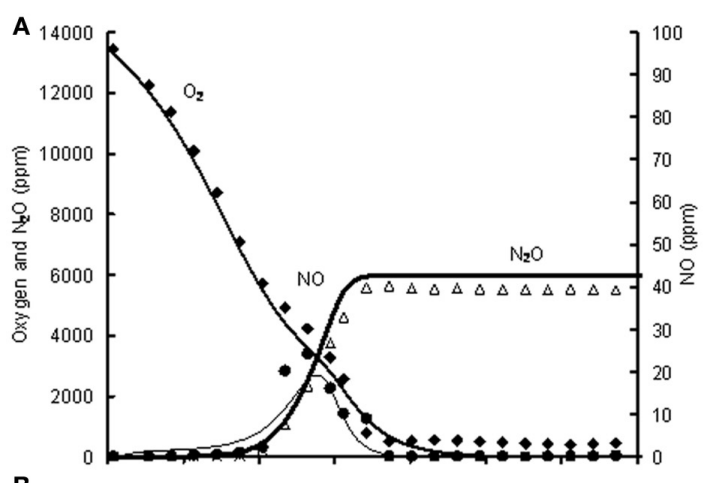

B

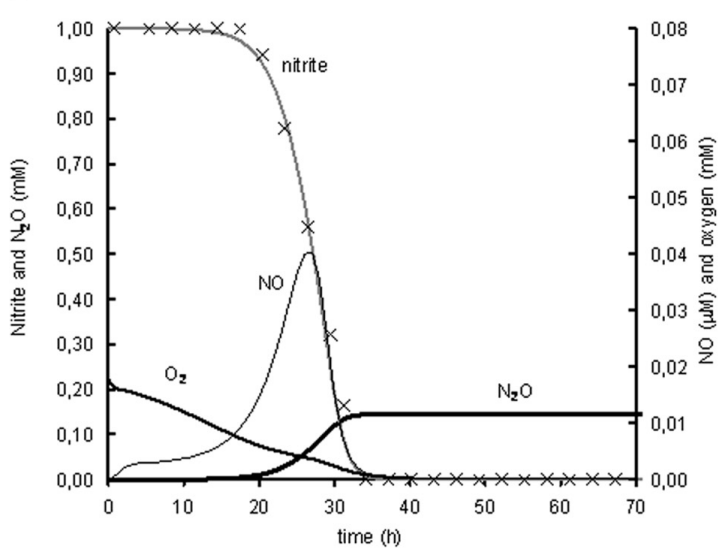

FIGURE 3 | Modeled (lines) and measured (points) concentrations during experiment with $1 \%$ gas phase oxygen and $1 \mathrm{mM}$ nitrite. (A) Gas phase concentrations of $\mathrm{O}_{2}(\bullet)$, $\mathrm{NO}(\bullet)$, and $\mathrm{N}_{2} \mathrm{O}(\Delta)$. (B) Liquid concentrations of $\mathrm{N}_{2} \mathrm{O}(\boldsymbol{L}), \mathrm{O}_{2}(-)$, nitrite $(x,-)$ ), and $\mathrm{NO}(-)$. (C) Liquid concentrations of expressed nir (-), measured nirk mRNA (O), expressed nor ( $\square$ ),

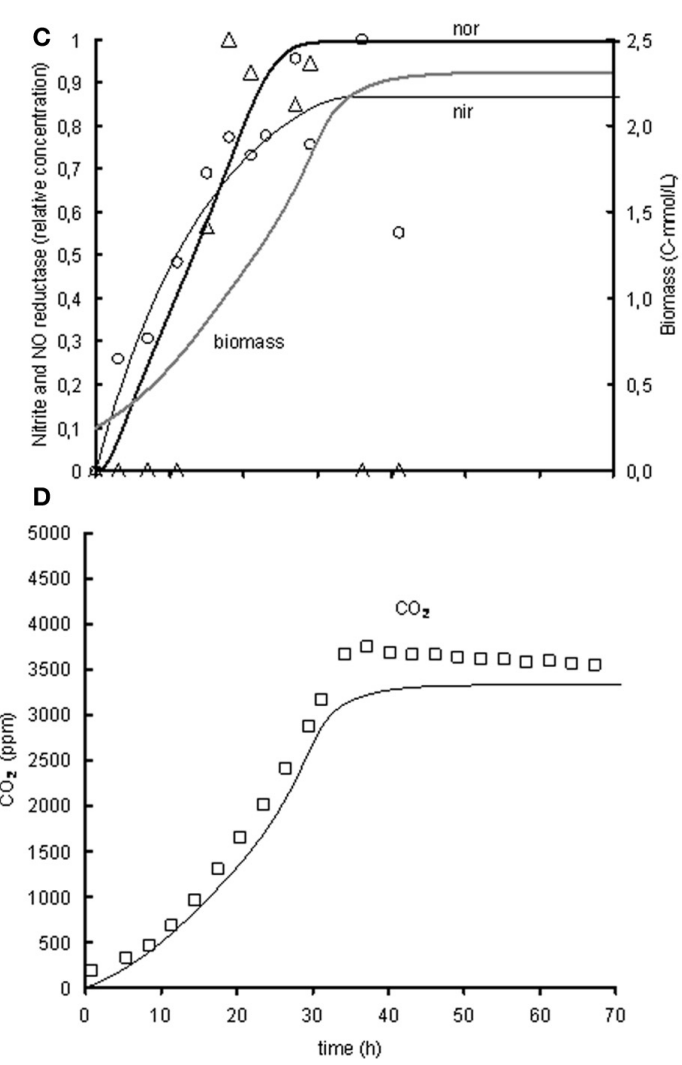

measured norB mRNA ( $\rho$ ), and biomass (-). (D) Gas phase concentration of $\mathrm{CO}_{2}(\square)$. The fit between the modeled data and the experimental data was assessed using the $R^{2}$-value: $\mathrm{R}^{2} \mathrm{O}_{2}=0.99, \mathrm{R}^{2} \mathrm{NO}=0.80, \mathrm{R}^{2} \mathrm{~N}_{2} \mathrm{O}=0.93$, $\mathrm{R}^{2} \mathrm{CO}_{2}=0.97$ with $R^{2}=1-\frac{\sum\left(\mathrm{C}_{\exp }-\mathrm{C}_{\text {model }}\right)^{2}}{\sum\left(\mathrm{C}_{\exp }-\overline{\mathrm{C}}_{\text {model }}\right)^{2}}$.
The gas-liquid mass transfer rate is:

$$
r_{\mathrm{tr}, i}=k_{L} a\left(\frac{c_{i}}{H_{i}}-C_{i}\right)
$$

The model solution and parameter estimation procedure were implemented numerically in Matlab (The Mathworks, Inc., Natick, MA, USA). The system of ordinary differential equations is solved from the initial conditions $\left(C_{i, 0}, c_{i, 0}\right.$, and $\left.E_{\text {sat }, i, 0}\right)$, including all reactions and mass transfer terms with the kinetic, physical and operational parameters presented in Table $\mathbf{1}$.

\section{MODEL PARAMETERS}

The rate parameters for microbial and enzyme kinetics were estimated based on the experimental data using the multivariable constrained optimization routine based on sequential quadratic methods (function fmincon from Matlab). The experimental parameters were based on the actual experiments. The model code can be found in Appendix I.

\section{RESULTS}

\section{METABOLIC MODEL OF THE BASE EXPERIMENT}

The model was based on the experiment with $1 \%$ oxygen in the headspace and $1 \mathrm{mM}$ nitrite as initial concentrations (see Figure 3 ).
The goodness of fit was analysed by calculating the SSE between the experimental data and the modeled values for the gaseous concentrations of $\mathrm{O}_{2}, \mathrm{NO}, \mathrm{N}_{2} \mathrm{O}$, and $\mathrm{CO}_{2}$. The gaseous concentrations of $\mathrm{O}_{2}, \mathrm{CO}_{2}$, and $\mathrm{N}_{2} \mathrm{O}$ are described very well by the metabolic model $\left(R^{2}>0.93\right)$, while the best fit for description of the NO concentration in the head-space was an $R^{2}$ of 0.8 (see heading of Figure 3 for goodness-of-fit data). As the NO accumulation is extremely small compared to the overall flux through the NO pool and several processes are dependent on the NO concentration, it was difficult to capture the trend of $\mathrm{NO}$ accumulation (for example, the NO accumulation between 23 and $26 \mathrm{~h}$ was $0.2 \%$ of the overall flux through the $\mathrm{NO}$ pool which is derived from the $\mathrm{N}_{2} \mathrm{O}$ accumulation). Also the modeled nitrite concentration and NorB and nirK transcription fit well with the measured data (see Figures $\mathbf{3 B}$ and C). The biomass growth during the experiment (see Figure 3C) clearly affects the conversion rates, which for example can be seen from the increase in volumetric oxygen uptake rates during the experiment.

A sensitivity analysis was performed to analyse the identifiability of the different parameters. For this purpose the normalized sensitivity was calculated. In the normalization the SSE is corrected for the average of the concentration of the different species to prevent bias due to difference in absolute concentration. The percentual change of the SSE_total upon a 10\% change of 
the separate parameters is presented in Table 2. This normalized change is an indication of the sensitivity and identifiability of the parameter.

$$
\begin{gathered}
\text { SSE_total }=\sum\left(\frac{\left(\mathrm{C}_{\text {exp }, \mathrm{O}_{2}}-\mathrm{C}_{\text {model }, \mathrm{O}_{2}}\right)^{2}}{\overline{\mathrm{C}_{\text {exp }, \mathrm{O}_{2}}}}+\frac{\left(\mathrm{C}_{\text {exp }, \mathrm{N}_{2} \mathrm{O}}-\mathrm{C}_{\text {model }, \mathrm{N}_{2} \mathrm{O}}\right)^{2}}{\overline{\mathrm{C}_{\text {exp }, \mathrm{N}_{2} \mathrm{O}}}}\right. \\
\left.+\frac{\left(\mathrm{C}_{\text {exp }, \mathrm{NO}}-\mathrm{C}_{\text {model }, \mathrm{NO}}\right)^{2}}{\overline{\mathrm{C}_{\text {exp }, \mathrm{NO}}}}+\frac{\left(\mathrm{C}_{\text {exp }, \mathrm{CO}_{2}}-\mathrm{C}_{\text {model }, \mathrm{CO}_{2}}\right)^{2}}{\overline{\mathrm{C}_{\text {exp }, \mathrm{CO}_{2}}}}\right) \\
\text { normalized change }=\frac{\left(\mathrm{SSE}_{10 \% \text { change }}-\mathrm{SSE}_{\mathrm{fit}}\right)}{\mathrm{SSE}_{\text {fit }}}
\end{gathered}
$$

This analysis demonstrated that the SSE increased dramatically upon changing the values of maximum biomass specific substrate uptake rate and the affinity constant for oxygen of the terminal oxidase. These parameters could be accurately identified since their values determine the exact time at which denitrification starts. Also the inhibition constant for $\mathrm{NO}$ on the oxygen respiration and the (apparent) inhibition of oxygen on nitrite and NO reduction were well identifiable. The substrate inhibition constant for NO reductase was poorly identifiable from this experiment (i.e., no significant change in the SSE when the parameter value was changed) because the NO concentrations do not reach the inhibitive concentration.

\section{APPLICATION OF THE MODEL TO OTHER EXPERIMENTS}

The metabolic model is based on the experiment with $1 \%$ oxygen gas phase and $1 \mathrm{mM}$ nitrite as initial concentrations. Subsequently, the model was extrapolated to the experiment with $1 \%$ oxygen gas phase and $1 \mathrm{mM}$ nitrate as initial concentrations. When modeling the nitrate experiment, the parameters identified in the nitrite experiment were used and only new parameters were added for the reduction of nitrate to nitrite. The modeled behavior of the oxygen uptake and $\mathrm{N}_{2} \mathrm{O}$ and $\mathrm{CO}_{2}$ production showed a relatively good correlation with the experimental data but the modeled NO concentrations were much lower than the measured NO concentrations (see Figure 4). This is further discussed in the model limitations section ("Model Limitations and Outlook").

The model was also applied to experiments at 0.2 and $2 \mathrm{mM}$ initial nitrite and nitrate and 1 and $7 \%$ of initial oxygen gas phase. The complete comparison between model results and experimental data on this additional data-set is shown in Appendix II. The model could describe oxygen consumption in these experiments relatively well, but the predicted $\mathrm{NO}$ and $\mathrm{N}_{2} \mathrm{O}$ emission did not correlate well with the experimental data. Obviously, a better fit could be generated if parameter values were adjusted for these individual experiments (now the parameter values were fitted on the $1 \%$ oxygen and $1 \mathrm{mM}$ nitrite/nitrate experiments). However, this would only generate limited additional insight. Especially the parameters involved in the enzyme synthesis could not be accurately defined (see Table 2) due to few experimental data. This might cause the poor fit of the $\mathrm{NO}$ and $\mathrm{N}_{2} \mathrm{O}$ concentrations when the model was used for different initial conditions, as enzyme synthesis in the model was highly dependent on the oxygen, nitrite, and NO concentrations. Additionally, in the experiments with higher initial oxygen concentrations oxygen depletion proceeded faster due to increased biomass presence, potentially leading to a different metabolic state of the cell (see "Model Limitations and Outlook" for further explanation).
These observations do indicate that some additional phenomena should be included in the model, to have a broader application range of the model. To identify additional phenomena additional experiments are needed, as described in the model limitation section ("Model Limitations and Outlook").

\section{DISCUSSION}

The use of the metabolic model and rate-based analysis of the experimental data enabled quantitative insight of the processes and increased understanding of the interdependence of the processes occurring during transition. For example, the NO accumulation was very tightly dependent on the combination of respiration and denitrification rates, as it also plays an inhibitory role on respiration. The model was used to test hypotheses that were based on the experimental observations (Bergaust et al., 2008) on the regulation of several phenomena in enzyme transcription and enzyme conversion kinetics, which are presented in the next section.

\section{ENZYME TRANSCRIPTION KINETICS AND ACTIVATORS Absence of interdependence of regulation of nitrite and NO reduction}

Generally it is assumed that nitrite and NO reduction are controlled interdependently, both at the expression and the enzyme activity level. Interdependent regulation of both enzymes is thought to secure minimal NO accumulation (Zumft, 1997). In P. denitrificans for example, nitrite reduction and NO reduction are interdependent; nor deprived mutants also stop nitrite reduction preventing accumulation of toxic levels of NO (de Boer et al., 1996). In A. tumefaciens such a mechanism seems to be absent since NO clearly accumulates to toxic levels upon rapid oxygen depletion and in the presence of elevated nitrite concentrations (see Appendix II).

The expression of nitrate reductase (periplasmic dissimilatory nitrate reductase, nap) is in many organisms regulated by nitrate and oxygen limitation (Zumft, 1997). Oxygen limitation as an inducer of nap transcription led to a slightly better fit of the modeled values to the experimental data than when only nitrate-induced nap transcription. Because nitrate was always present in the experiments with nitrate reduction and no nap transcription measurements were performed, the effect of nitrate could not be identified and subsequently only oxygen limitation was used in the metabolic model for description of nap transcription.

\section{ENZYME KINETICS \\ NO inhibits oxygen respiration}

NO clearly inhibits oxygen reduction as shown in the experiments with $1 \%$ oxygen atmosphere and $1 \mathrm{mM}$ nitrite (Figure 3 ) and $2 \mathrm{mM}$ nitrite (see Appendix II). NO is an important signaling compound and has been shown to inhibit terminal oxidases in mitochondria of eukaryotes (Giuffre et al., 1996; Sarti et al., 2000) and bacterial terminal oxidases (Borisov et al., 2004). Including NO inhibition in the metabolic model greatly improved the description of the experimental data. At the lower nitrite concentrations, nor expression is adequately fast to prevent $\mathrm{NO}$ accumulation up to inhibitory levels. In the nitrate experiments NO inhibition on oxygen respiration could not be identified because NO is only formed in significant amounts after oxygen is depleted.

\section{NO inhibition of nitrate reductase does not occur}

In the paper of Bergaust et al. (2008) inhibition of nitrate reductase by NO was hypothesized as an explanation why NO did not 

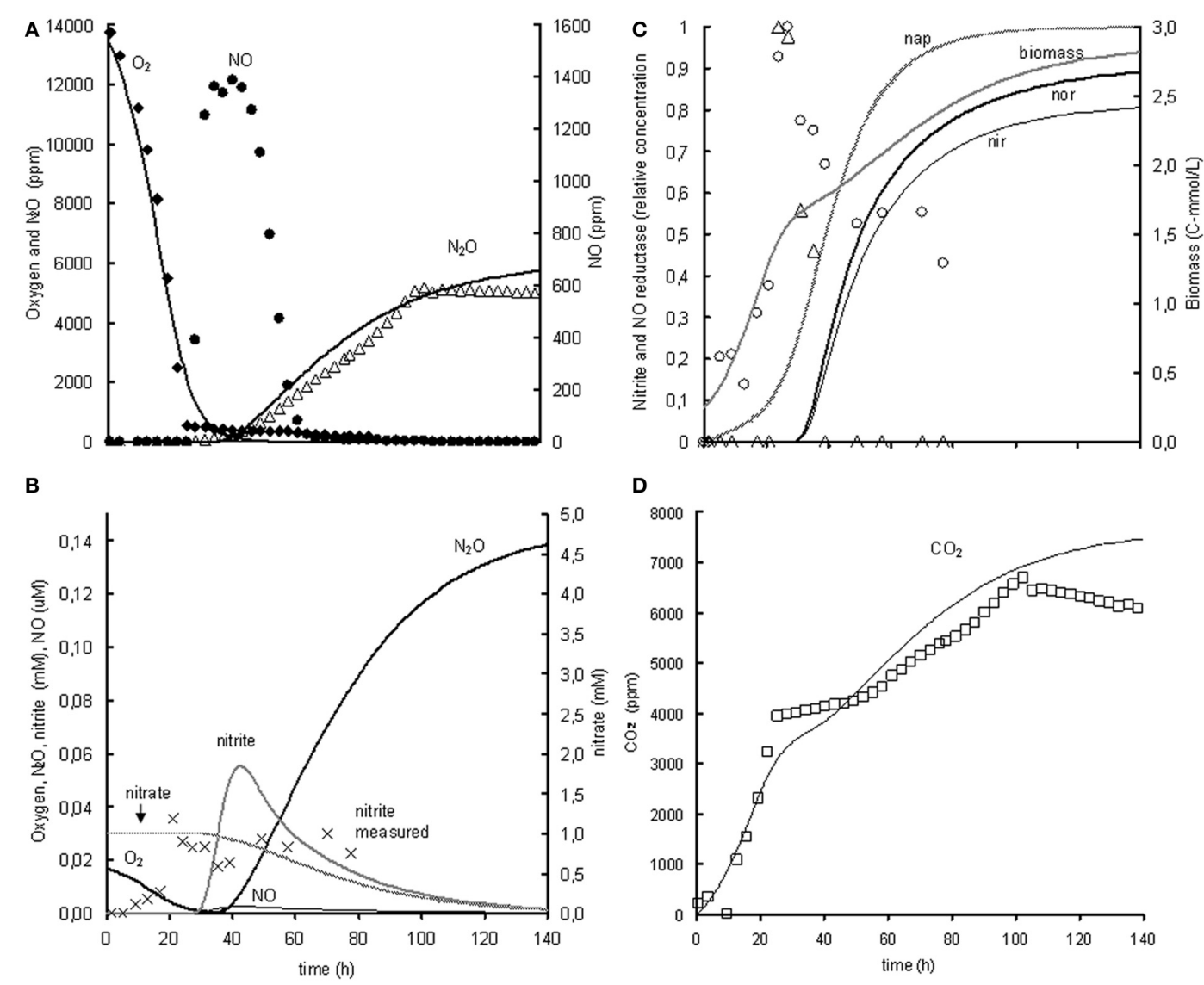

\section{D}

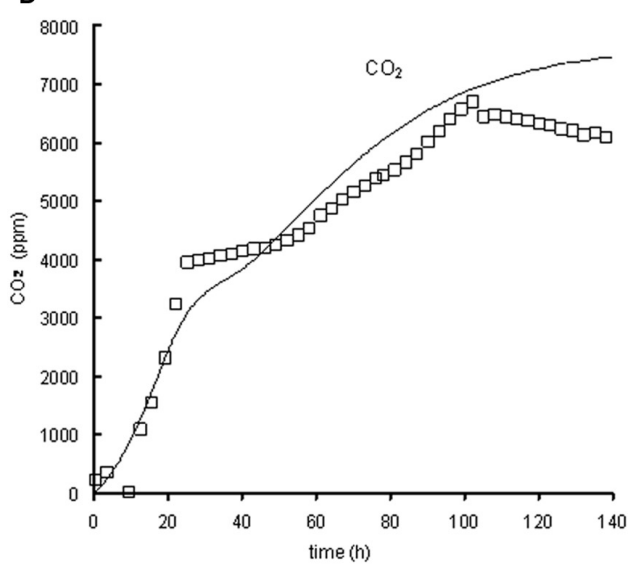

FIGURE 4 | Modeled (lines) and measured (points) concentrations when extrapolating the metabolic model to the experiment with $1 \%$ gas phase oxygen and $1 \mathrm{mM}$ nitrate. (A) Gas phase concentrations of $\mathrm{O}_{2}(\bullet), \mathrm{NO}(\bullet)$, and $\mathrm{N}_{2} \mathrm{O}(\Delta)$. (B) Liquid concentrations of $\mathrm{N}_{2} \mathrm{O}(\boldsymbol{\square}), \mathrm{O}_{2}(\mathbf{C})$, nitrate $(-)$, nitrite $(x,-)$, and $\mathrm{NO}(-)$. (C) Liquid concentrations of expressed nap $(--)$, expressed nir (-), measured nirK mRNA (O), expressed nor $(-)$, measured norB mRNA $(\Delta)$, and biomass $(-)$. (D) Gas phase concentration

of $\mathrm{CO}_{2}(\square)$. The fit between the modeled data and the experimental data was assessed using the $R^{2}$-value: $R^{2} \mathrm{O}_{2}=0.98, R^{2} \mathrm{NO}=-0.29, R^{2} \mathrm{~N}_{2} \mathrm{O}=0.85$, $R^{2} \mathrm{CO}_{2}=0.80$ with $R^{2}=1-\frac{\sum\left(C_{\exp }-\mathrm{C}_{\text {model }}\right)^{2}}{\sum\left(C_{\exp }-\overline{\mathrm{C}}_{\text {model }}\right)^{2}}$. The negative $R^{2}$ for $\mathrm{NO}$ is caused by the poor description of the experimental NO concentrations by the model. Consequently, the sum of squared errors for the model description was larger than the sum of the variance of the experimental values.

Table 2 | Normalized change (\%) in sum of squared errors for the parameters in the metabolic model.

\begin{tabular}{|c|c|c|c|c|c|c|c|c|c|c|}
\hline \multirow[t]{2}{*}{ Parameter change } & \multicolumn{2}{|c|}{$\begin{array}{c}\text { Change SSE } \\
\text { total (\%) }\end{array}$} & \multicolumn{2}{|c|}{$\begin{array}{c}\text { Change SSE } \\
\text { oxygen (\%) }\end{array}$} & \multicolumn{2}{|c|}{$\begin{array}{c}\text { Change SSE } \\
\text { NO (\%) }\end{array}$} & \multicolumn{2}{|c|}{$\begin{array}{c}\text { Change SSE } \\
\mathrm{N}_{2} \mathrm{O}(\%)\end{array}$} & \multicolumn{2}{|c|}{$\begin{array}{c}\text { Change SSE } \\
\mathrm{CO}_{2}(\%)\end{array}$} \\
\hline & $-10 \%$ & $+10 \%$ & $-10 \%$ & $+10 \%$ & $-10 \%$ & $+10 \%$ & $-10 \%$ & $+10 \%$ & $-10 \%$ & $+10 \%$ \\
\hline k_nir & 0.2 & 0.0 & 1.7 & -1.0 & 4.5 & -3.0 & -0.8 & 0.7 & -0.5 & 0.5 \\
\hline k_nor & 0.4 & 0.1 & -0.2 & 0.7 & -0.1 & 0.4 & -1.7 & 2.0 & 3.2 & -2.6 \\
\hline q_succ & 139 & 88 & 180 & 148 & 115 & 22 & 135 & 155 & 105 & -40 \\
\hline $\mathrm{K} \_\mathrm{NO}_{2} \_\mathrm{NIR}$ & 0.00 & 0.00 & -0.06 & 0.06 & -0.17 & 0.18 & 0.05 & -0.05 & 0.02 & -0.02 \\
\hline K_NO_NorB & 0.0 & 0.3 & 0.7 & -0.2 & 0.0 & 0.2 & 1.9 & -1.4 & -2.5 & 2.5 \\
\hline $\mathrm{K} \_\mathrm{O}_{2}$ & 20 & 26 & 42 & 32 & -22 & 41 & 45 & 9 & -26 & 35 \\
\hline KI_NO & 0.00 & 0.00 & 0.00 & 0.00 & -0.03 & 0.03 & -0.02 & 0.02 & 0.02 & -0.02 \\
\hline KI_NO_resp & 4 & 1 & 3 & 3 & 14 & -11 & -3 & 8 & 10 & -8 \\
\hline
\end{tabular}


further accumulate anymore but stayed at a constant concentration. The model runs clearly showed that this cannot be the case, as even though the concentration was constant there was a large flux through the NO-pool. In other words, the production and consumption of $\mathrm{NO}$ was constant, but nitrate was still consumed and $\mathrm{N}_{2} \mathrm{O}$ produced.

\section{Oxygen inhibits all denitrification conversions}

NirK and norB are already transcribed in the presence of oxygen (see previous section). Nevertheless, denitrification activity mainly occurs when oxygen concentrations are low. This suggests that oxygen apparently inhibits the denitrification reactions. However, literature information indicates that oxygen does not directly inhibit the enzymes in the denitrification pathways, except for $\mathrm{N}_{2} \mathrm{O}$ reductase (Zumft, 1997). Consequently, the oxygen inhibition observed is likely the result of preferred electron flow towards aerobic respiration rather than anoxic respiration.

\section{NO accumulates after rapid oxygen depletion}

Exceptionally high NO accumulation occurred in the experiments with a higher initial oxygen concentration (7\%, see Appendix II). These experiments are characterized by very rapid oxygen depletion, because of the high biomass accumulation as a result of the long oxic growth phase. Apparently, the cell metabolism cannot respond adequately to such a rapid oxygen depletion leading to imbalanced expression of the denitrification pathway. It seems that nor $B$ transcription and translation suffers most heavily from this imbalance, possibly because NO reduction is the last conversion in the denitrification pathway and the norB transcription is activated by NO.

In the $1 \mathrm{mM}$ nitrate experiment with $1 \%$ initial oxygen in the gas phase (Figure 4, panel C), it appears that norB transcription even stops when oxygen is depleted, even though $\mathrm{NO}$ and nitrite are still present.

Experiments with repeated oxygen addition indicated that oxygen addition was beneficial for recovery of the denitrification metabolism after cells had suffered from rapid oxygen depletion (see Appendix III). Oxygen addition led to an increase of the NO reduction rates. This should be further investigated in experiments where quantification of nor expression is included.

A beneficial role of residual oxygen presence during transition from aerobic to anoxic respiration on nitrate in A. tumefaciens was also observed by Baek and Shapleigh (2005). In various Pseudomonas species it was observed that expression of denitrification enzymes during oxygen limitation can lead to low activity of nor. In these experiments nitrate was reduced for more than $85 \%$ to $\mathrm{NO}$ as final product by 6 of the 10 Pseudomonas strains which normally catalyze complete denitrification to $\mathrm{N}_{2}$ (Frunzke and Zumft, 1986). In P. denitrificans and Pseudomonas SpG59 residual oxygen respiration during anoxic adaptation is required for induction of the denitrification pathway (Kucera et al., 1984; Aida et al., 1986) which was concluded to be a characteristic property of (non-fermentative) facultative denitrifiers (Mazoch et al., 2003).

\section{MODEL LIMITATIONS AND OUTLOOK}

This study demonstrates that the development of a metabolic model improves the level of understanding of the experimental results obtained with A. tumefaciens (Bergaust et al., 2008) as it offers a structured look on the processes occurring in the cell. Even though most phenomena could also be identified based on the experimental data, the metabolic model increased understanding. In addition it could be effectively used to identify parameter values (like affinity and inhibition constants), to test hypotheses and will be a good tool in designing new experiments. The model is not intended as a generic metabolic model of the denitrification process.

Extrapolation of the model to the experiment with $1 \%$ oxygen gas phase and $1 \mathrm{mM}$ nitrate as initial concentrations revealed that the denitrification rate with nitrate is much lower than with nitrite as electron acceptor. Consequently, a very low nitrate affinity had to be used when using the metabolic model for description of the nitrate experiments when keeping the conversions and enzyme transcription kinetics from nitrite to $\mathrm{N}_{2} \mathrm{O}$ the same. Because the nitrate reduction was slower than the nitrite and $\mathrm{NO}$ reduction, the model predicted insignificant accumulation of nitrite and NO. In the experiments however, significant NO accumulation occurred, which can either be due to increased NO production or by decreased NO consumption. As the nitrite reduction rate in the nitrate experiments is already lower than in the nitrite experiments, it is most plausible that the NO reduction is lower than expected based on the nitrite experiments. This can be caused by decreased norB transcription, decreased nor translation or decreased activity of the NO reductase. Further experiments are needed to identify the exact mechanism.

Currently, not all experiments could be adequately described by the model (see Appendix II). This means that based on the present experimental data-set, some important phenomena could not be identified and additional experiments are needed to improve the model. All experiments described here were batch experiments, characterized by dramatic changes in environmental conditions. Specifically at higher oxygen concentrations the transition from aerobic to anoxic conditions is very fast due to increased biomass concentrations. To which extent these rapid changes affect the overall metabolic state of the cell and the capacity to adjust the metabolism to different conditions remains unclear. To investigate the response of the system to the rates of transition, continuous supply of substrates or products to the experimental system could be applied. Understanding of the regulation network can be further increased by additional measurements of mRNA for known nitrogen oxide sensors and subsequent extension of the metabolic model. Improved parameter estimation could furthermore be established by experiments with external supply of NO, the key intermediate in the denitrification pathway. This may enable improved estimation of inhibition and affinity constants and allow to distinguish better between the effects of nitrite, NO and oxygen limitation.

\section{ENVIRONMENTAL CONSEOUENCES OF IDENTIFIED BEHAVIOR DURING OXIC-ANOXIC TRANSITION}

The experimental data of $A$. tumefaciens clearly show that transition from oxic to anoxic conditions can lead to emission of NO. Two circumstances are responsible for increased emission during transition:

(a) Quick depletion of oxygen; this was found to give rise to incomplete expression of the denitrification pathway and consequently to the increased emission of intermediates,

(b) Presence of nitrite (already in micromolar range); this resulted in expression of denitrification enzymes and conversion in presence of oxygen.

The characterized independent regulation of nirK and norB transcription can further increase emission since the expression levels of the individual enzymes can easily be unbalanced. 
Dynamic systems that are characterized by rapid transitions from aerobic to anoxic conditions were shown to give rise to increased emissions of $\mathrm{NO}$ and $\mathrm{N}_{2} \mathrm{O}$ in practice (Burgess et al., 2002; Kampschreur et al., 2008). $\mathrm{NO}$ and $\mathrm{N}_{2} \mathrm{O}$ emissions from oxygen-limiting, nitritecontaining environments have also been observed (Schulthess et al., 1995; Sümer et al., 1995).

Denitrifying organisms are diverse in their regulation of the denitrification pathway (Rodionov et al., 2005), which means that phenomena that were identified for Agrobacterium cannot be directly translated towards all facultative denitrifiers. Nevertheless, most phenomena described here have also been identified in other organisms [like P. denitrificans, R. sphaeriodes (Baker et al., 1998), Pseudomonas (Frunzke and Zumft, 1986), and Escherichia coli and Azotobacter vinelandii (Borisov et al., 2004)].

\section{ACKNOWLEDGMENTS}

We would like to thank Dr. Emrah Nickerel for assistance on parameter identifiability analysis of the model. The project was funded by the Dutch Foundation for Applied Sciences STW under grant NBC.6352.

\section{REFERENCES}

Aida, T., Hata, S., and Kusunoki, H. (1986). Temporary low oxygen conditions for the formation of nitrate reductase and nitrous oxide reductase by denitrifying Pseudomonas sp. G59. Can. J. Microbiol. 32, 543-547.

Baek, S.-H., Hartsock, A., and Shapleigh, J. P. (2008). Agrobacterium tumefaciens C58 uses ActR and FnrN to control nirK and nor expression. J. Bacteriol. 190, 78-86.

Baek, S.-H., and Shapleigh, J. P. (2005). Expression of nitrite and nitric oxide reductases in free-living and plant-associated Agrobacterium tumefaciens C58 cells. Appl. Environ. Microbiol. 71, 4427-4436.

Baker, S. C., Ferguson, S. J., Ludwig, B., Page, M. D., Richter, O.-M. H., and Van Spanning, R. J. M. (1998). Molecular genetics of the genus Paracoccus: metabolically versatile bacteria with bioenergetic flexibility. Microbiol. Mol. Biol. Rev. 62, 1046-1078.

Bergaust, L., Shapleigh, J., Frostegard, A., and Bakken, L. (2008). Transcription and activities of NOx reductases in Agrobacterium tumefaciens: the influence of nitrate, nitrite and oxygen availability. Environ. Microbiol. 10, 3070-3081.

Beun, J. J., Verhoef, E. V., Van Loosdrecht, M. C. M., and Heijnen, J. J. (2000). Stoichiometry and kinetics of poly-b-hydroxybutyrate metabolism under denitrifying conditions in activated sludge cultures. Biotechnol. Bioeng. 68, 496-507.

Borisov, V. B., Forte, E., Konstantinov, A. A., Poole, R. K., Sarti, P., and Giuffre, A. (2004). Interaction of the bacterial terminal oxidase cytochrome bd with nitric oxide. FEBS Lett. 576, 201-204.

Burgess, J. E., Stuetz, R. M., Morton, S., and Stephenson, T. (2002). Dinitrogen oxide detection for process failure early warning systems. Water Sci. Technol. 45, 247-254.

de Boer, A. P., van der Oost, J., Reijnders, W. N., Westerhoff, H. V., Stouthamer, A. H., and van Spanning, R. J. (1996). Mutational analysis of the nor gene cluster which encodes nitric-oxide reductase from Paracoccus denitrificans. Eur. J. Biochem. FEBS 242, 592-600.

Ferguson, S. J. (1994). Denitrification and its control. Antonie Van Leeuwenhoek 66, 89-110.

Frunzke, K., and Zumft, W. G. (1986). Inhibition of nitrous oxide respiration by nitric oxide in the denitrifying bacterium Pseudomonas perfectomarina. Biochim. Biophys. Acta 852, 119-125.

Girsch, P., and de Vries, S. (1997). Purification and initial kinetic and spectroscopic characterization of NO reductase from Paracoccus denitrificans. Biochim. Biophys. Acta 1318, 202-216.

Giuffre, A., Sarti, P., D’Itri, E., Buse, G., Soulimane, T., and Brunori, M. (1996). On the mechanism of inhibition of cytochrome c oxidase by nitric oxide. J. Biol. Chem. 271, 33404-33408.

Heijnen, J. J. (1999). "Bioenergetics of microbial growth," in Encyclopedia of Bioprocess Technology: Fermentation, Biocatalysis, and Bioseparation, eds M. C. Flickinger and S. W. Drew (New York, NY: Wiley-Interscience), 267-291.

Houghton, J. T., Ding, Y., Griggs, D. J., Noguer, M., van der Linden, P. J., and Dai, X. (2001). "Climate change 2001," in The Scientific Basis. Contribution of Working Group I to the Third Assessment Report of the Intergovernmental Panel on Climate Change, eds K. Maskell and C. A. Johnson (Cambridge, UK, New York, NY, USA: Cambridge University Press), 881.

Kampschreur, M. J., van der Star, W. R. L., Wielders, H. A., Mulder, J. W., Jetten, M. S. M., and van
Loosdrecht, M. C. M. (2008). Dynamics of nitric oxide and nitrous oxide emission during full-scale reject water treatment. Water Res. 42, 812-826.

Kucera, I., Boublikova, P., and Dadak, V. (1984). Function of terminal acceptors in the biosynthesis of denitrification pathway components in Paracoccus denitrificans. Folia Microbiol. 29, 108-114.

Mazoch, J., Kunak, M., Kucera, I., and van Spanning, R. J. M. (2003). Fine-tuned regulation by oxygen and nitric oxide of the activity of a semi-synthetic FNR-dependent promoter and expression of denitrification enzymes in Paracoccus denitrificans. Microbiology 149, 3405-3412.

Parkhurst, D., and Appelo, C. A. J. (1999). User's Guide to PHREEQC (Version 2), a Computer Program for Speciation, Batch-Reaction, One-Dimensional Transport, and Inverse Geochemical Calculations, Water Resources Investigation Report 99-4259, US. Geological Survey, Denver, CO.

Ravishankara, A. R., Daniel, J. S., and Portmann, R. W. (2009). Nitrous oxide (N2O): the dominant ozone-depleting substance emitted in the 21st century. Science 326 , 123-125.

Rodionov, D. A., Dubchak, I. L., Arkin, A. P., Alm, E. J., and Gelfand, M. S. (2005). Dissimilatory metabolism of nitrogen oxides in bacteria: comparative reconstruction of transcriptional networks. PLoS Comput. Biol. 1, 415-431.

Sander, R. (1999). Compilation of Henry's law constants for inorganic and organic species of potential importance in environmental chemistry, version 3 , max-planck institute of chemistry, mainz, Germany. Available online at: http://www.mpchmainz.mpg.de/ sander/res/henry. html

Sarti, P., Giuffre, A., Forte, E., Mastronicola, D., Barone, M.
C., and Brunori, M. (2000). Nitric oxide and cytochrome $c$ oxidase: mechanisms of inhibition and NO degradation. Biochem. Biophys. Res. Commun. 274, 183-187.

Schulthess, R. V., Kuehni, M., and Gujer, W. (1995). Release of nitric and nitrous oxides from denitrifying activated sludge. Water Res. 29, 215-226.

Schuster, M., and Conrad, R. (1992). Metabolism of nitric oxide and nitrous oxide during nitrification and denitrification in soil at different incubation conditions. FEMS Microbiol. Ecol. 101, 133-143.

Sümer, E., Weiske, A., Benckiser, G. and Ottow, J. C. G. (1995). Influence of environmental conditions on the amount of $\mathrm{N} 2 \mathrm{O}$ released from activated sludge in a domestic waste water treatment plant. Experientia 51, 419-422.

Stouthamer, A. H. (1979). The search for correlation between theoretical and experimental growth yields. Int. Rev. Biochem. 21, $1-47$.

Thomsen, J. K., Geest, T., and Cox, R. P. (1994). Mass spectrometric studies of the effect of $\mathrm{pH}$ on the accumulation of intermediates in denitrification by Paracoccus denitrificans. Appl. Environ. Microbiol. 60, 536-541.

Wasser, I. M., de Vries, S., MoeenneLoccoz, P., Schroeder, I., and Karlin, K. D. (2002). Nitric oxide in biological denitrification: Fe/Cu metalloenzyme and metal complex NOx redox chemistry. Chem. Rev. 102, 1201-1234.

Wild, D., Schulthess, R. V., and Gujer, W. (1994). Synthesis of denitrification enzymes in activated sludge: modeling with structured biomass. Water Sci. Technol. 30, 113-122.

Wood, D. W., Setubal, J. C., Kaul, R., Monks, D. E., Kitajima, J. P., Okura, V. K., et al. (2001). The genome of the natural genetic 
engineer Agrobacterium tumefaciens C58. Science 294, 2317-2323.

Zumft, W. G. (1997). Cell biology and molecular basis of denitrification. Microbiol. Mol. Biol. Rev. 61, 533-616.

Conflict of Interest Statement: The authors declare that the research was conducted in the absence of any commercial or financial relationships that could be construed as a potential conflict of interest.

Received: 29 March 2012; accepted: 28 September 2012; published online: 18 October 2012

Citation: Kampschreur MJ, Kleerebezem R, Picioreanu C, Bakken L, Bergaust $L$, de Vries $S$, Jetten MSM and van
Loosdrecht MCM (2012) Metabolic modeling of denitrification in Agrobacterium tumefaciens: a tool to study inhibiting and activating compounds for the denitrification pathway. Front. Microbio. 3:370. doi: 10.3389/ fmicb.2012.00370

This article was submitted to Frontiers in Evolutionary and Genomic Microbiology, a specialty of Frontiers in Microbiology.
Copyright (C) 2012 Kampschreur, Kleerebezem, Picioreanu, Bakken, Bergaust, de Vries, Jetten and Van Loosdrecht. This is an open-access article distributed under the terms of the Creative Commons Attribution License, which permits use, distribution and reproduction in other forums, provided the original authors and source are credited and subject to any copyright notices concerning any third-party graphics etc. 


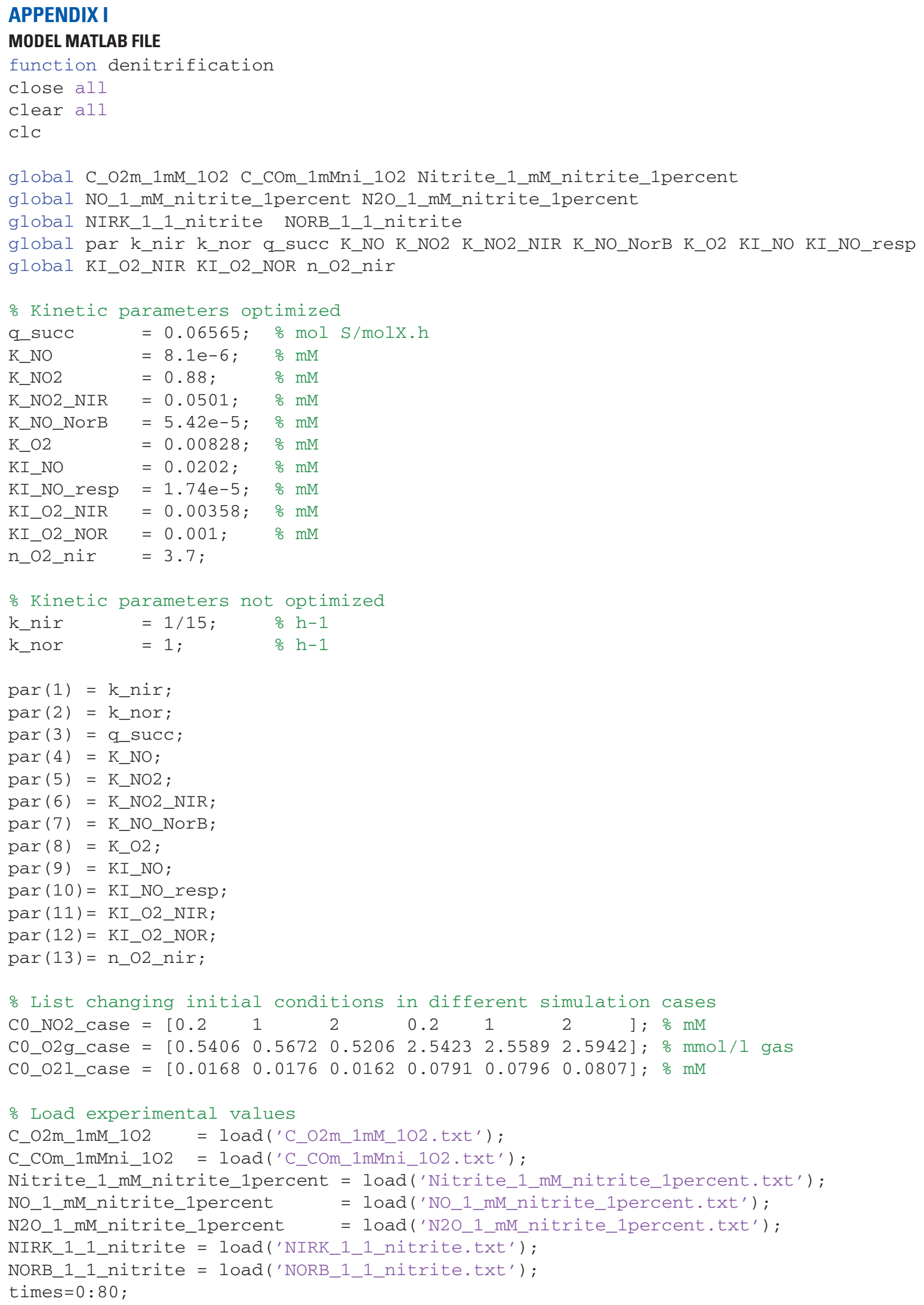


\% Current simulation case

for ncase=1:6; \%for all cases

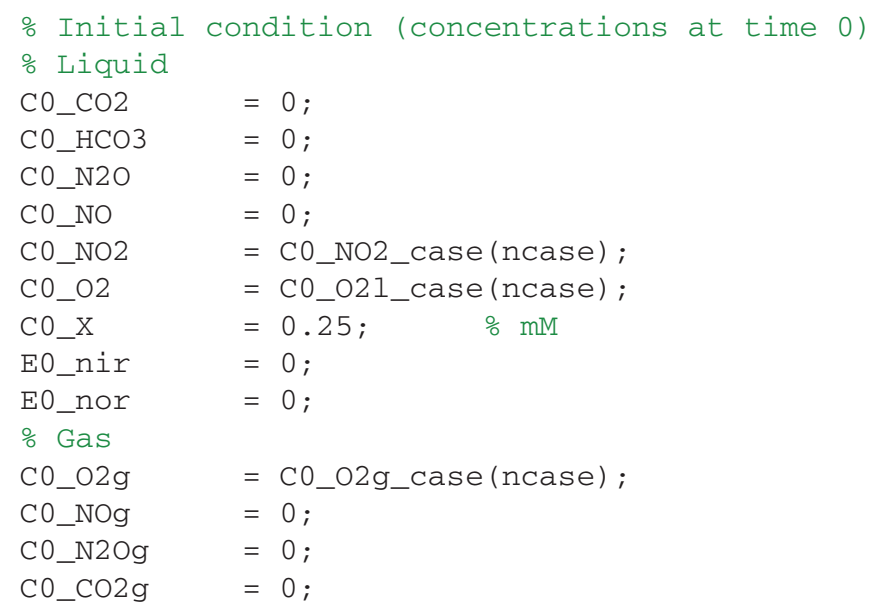

$\begin{array}{lllllllllllll}\circ & 1 & 2 & 3 & 4 & 5 & 6 & 7 & 8 & 9 & 10 & 11 & 12\end{array}$

$\mathrm{CO}=\left[\mathrm{CO} \_\mathrm{CO} 2 \mathrm{CO} \_\mathrm{HCO} 3\right.$ C0_N2O CO_NO CO_NO2 CO_O2 C0_X E0_nir E0_nor CO_O2g C0_NOg C0_N2Og CO_CO2g]';

options $=\operatorname{odeset}(' \operatorname{RelTol}$ ', 1e-3,'AbsTol', 1e-6);

$[\mathrm{T}, \mathrm{Y}]=\operatorname{ode} 23 \mathrm{~s}(\ldots$

abalances,... \% name function containing ODE

times,... $\%$ time interval to simulate

Co,... \% initial values

options); $\quad$ o options ODE solver

\% printing of model data to text file

ntimes = length $(\mathrm{T})$;

fid = fopen(['Simulation_nitrite_final' num2str(ncase) '.txt'], 'wt');

fprintf(fid, ' $\% 15 \mathrm{~s} \% 15 \mathrm{~s} \% 15 \mathrm{~s} \% 15 \mathrm{~s} \% 15 \mathrm{~s} \% 15 \mathrm{~s} \% 15 \mathrm{~s} \% 15 \mathrm{~s} \% 15 \mathrm{~s} \% 15 \mathrm{~s} \% 15 \mathrm{~s} \% 15 \mathrm{~s} \% 15 \mathrm{~s} \% 15 \mathrm{~s} \backslash \mathrm{n}^{\prime}$,

'time', 'C_CO2', 'C_HCO3', 'C_N2O', 'C_NO', 'C_NO2', 'C_O2',

'C_X', 'E_nir', 'E_nor',

'C_O2g', 'C_NOg', 'C_N2Og', 'C_CO2g') ;

for $i=1:$ ntimes

fprintf(fid, \%15.5e\%15.5e\%15.5e\%15.5e\%15.5e\%15.5e\%15.5e\%15.5e\%15.5e\%15.5e\%15.5e\%15.5e

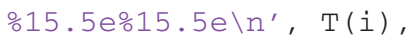

$Y(i, 1), Y(i, 2), Y(i, 3), Y(i, 4), Y(i, 5), Y(i, 6)$,

end

$Y(i, 7), Y(i, 8), Y(i, 9), Y(i, 10), Y(i, 11), Y(i, 12), Y(i, 13))$;

fclose (fid):

end

end

\section{BALANCES MATLAB FILE}

function dcdt $=$ balances $(t, y)$

global par

k_nir $\quad=\operatorname{par}(1)$;

k_nor $\quad=\operatorname{par}(2)$;

q_succ $\quad=\operatorname{par}(3)$;

K_NO $\quad=\operatorname{par}(4)$;

K_NO2 $=\operatorname{par}(5)$; 


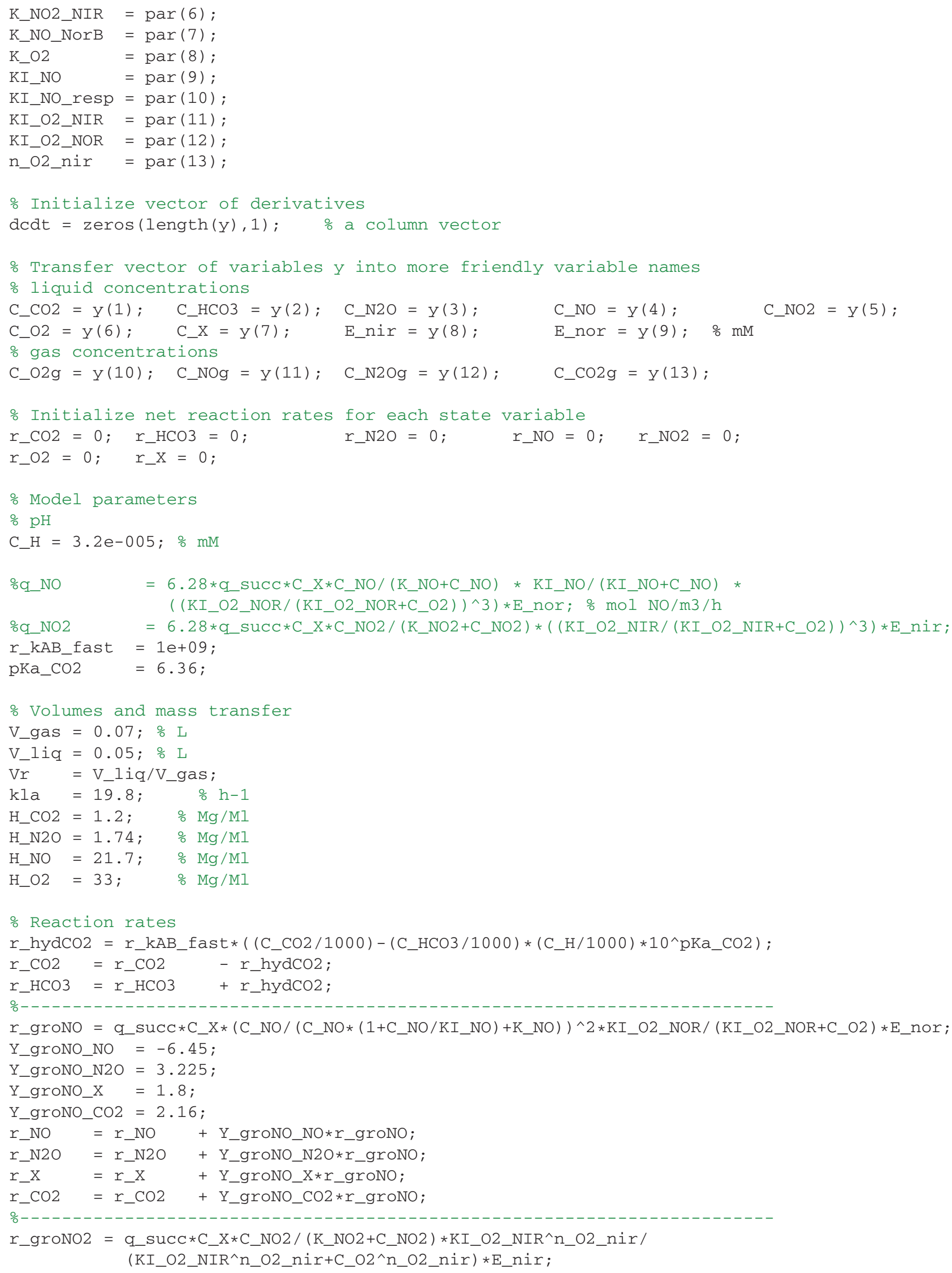




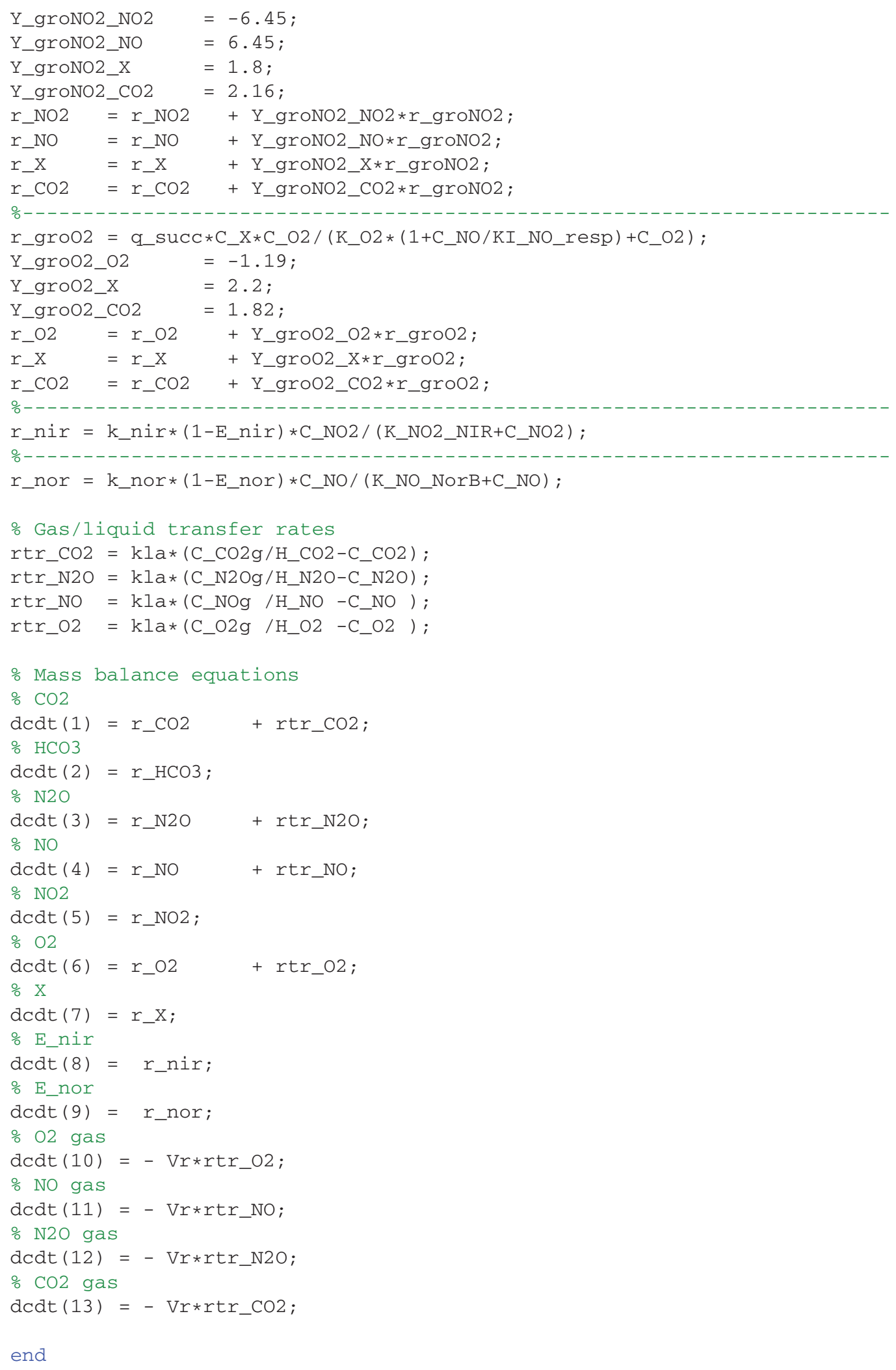




\section{APPENDIX II}

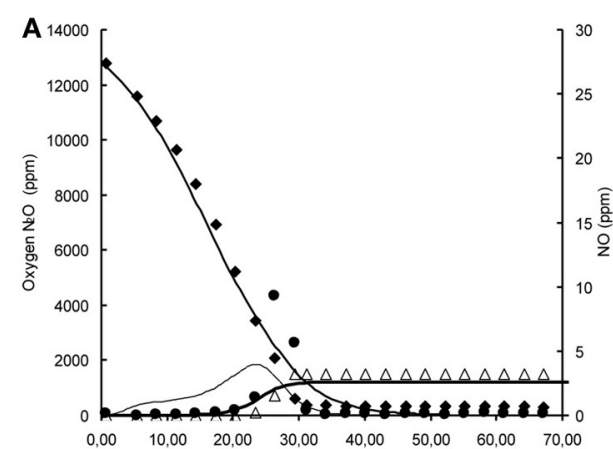

B

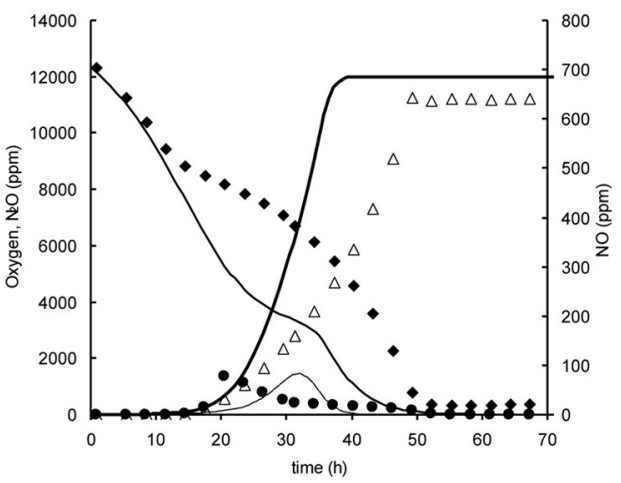

FIGURE A1 | Modeled (lines) and measured (points) gas phase concentrations of oxygen $(\diamond), \mathrm{NO}(\bullet)$, and $\mathrm{N}_{2} \mathrm{O}(\Delta)$ during experiments at $1 \%$ initial oxygen concentration in headspace with

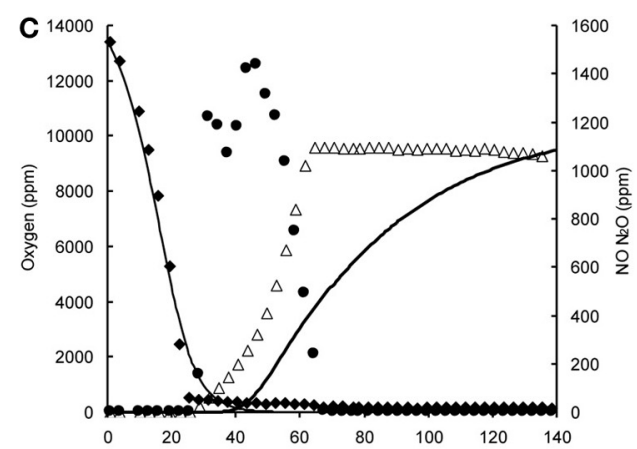

D

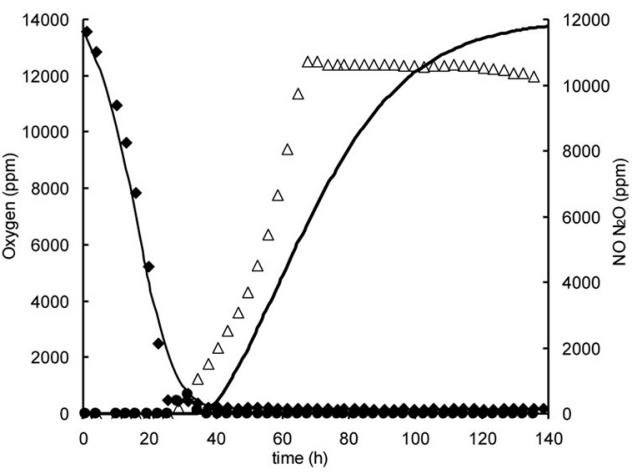

nitrite and nitrate in the liquid phase at $\mathbf{0 . 2}$ and $\mathbf{2} \mathbf{~ m M}$. (A) $1 \%$ oxygen, $0.2 \mathrm{mM}$ nitrite. (B) $1 \%$ oxygen $2 \mathrm{mM}$ nitrite. (C) $1 \%$ oxygen, $0.2 \mathrm{mM}$ nitrate. (D) $1 \%$ oxygen, $2 \mathrm{mM}$ nitrate. 


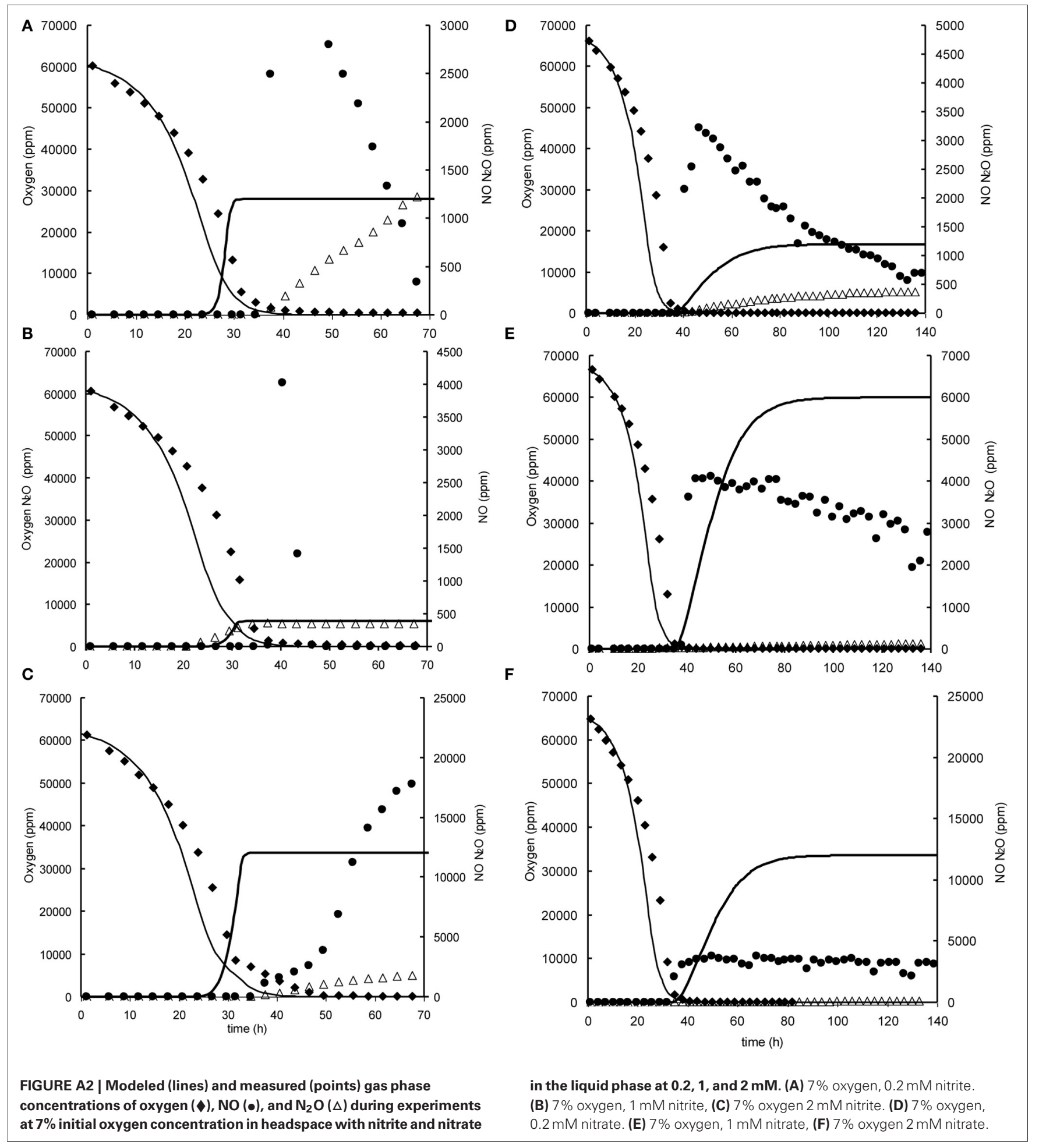




\section{APPENDIX III \\ OXYGEN INFLUENCE ON NO REDUCTION CAPACITY}

Additional experiments were performed in $120 \mathrm{ml}$ serum flasks, containing $50 \mathrm{ml}$ Sistrom's medium (see Bergaust et al., 2008) with $34 \mathrm{mM}$ succinate as the only $\mathrm{C}$ source and different concentrations of $\mathrm{KNO}_{2}$. The initial oxygen concentration in the headspace was increased to $13 \%$ oxygen in the headspace. Inocula of fully dispersed, aerobically grown, late exponential cells of Agrobacterium tumefaciens, which had not been previously exposed to anoxic conditions, were injected into the flasks. When oxygen depletion occurred, oxygen was added again to the headspace of the flasks. Figure A3, shows an example of an experiment in which after oxygen addition NO reduction rates increased.

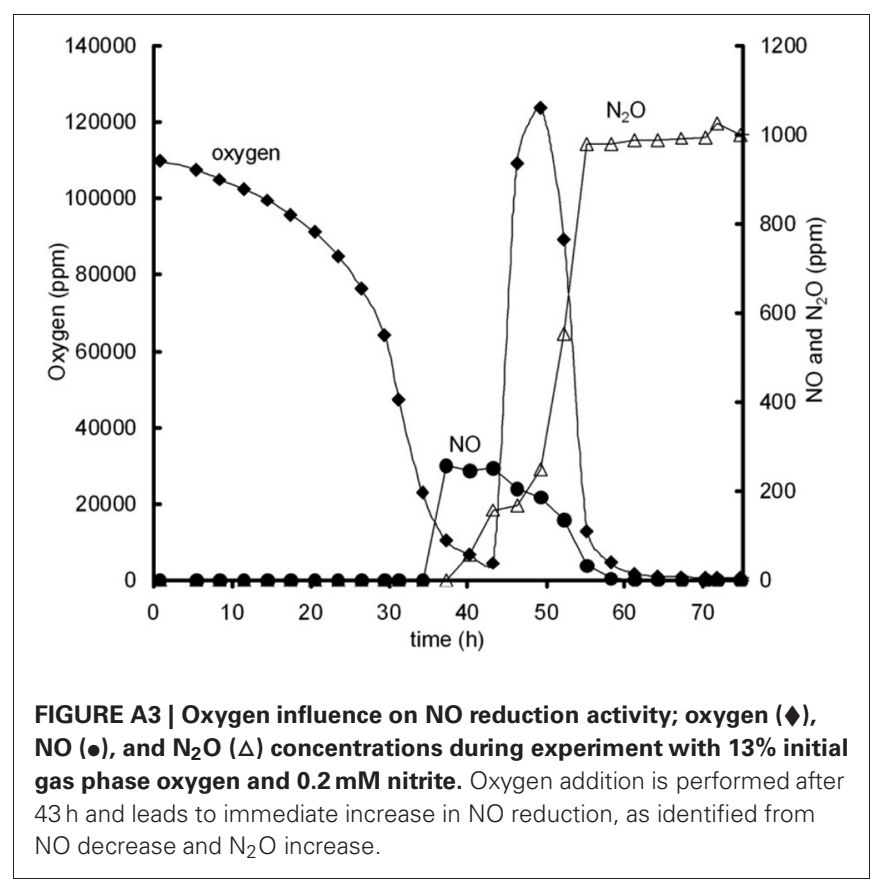

